\title{
Review \\ Development, Diversity, and Death of MGE-Derived Cortical Interneurons
}

\author{
Rhîannan H. Williams ${ }^{1}$ (D) and Therese Riedemann ${ }^{2, *(D)}$ \\ 1 Helmholtz Zentrum München, German Research Centre for Environmental Health, Institute for Neurogenomics, \\ Ingolstädter Landstraße 1, 85764 Neuherberg, Germany; rhiannan.williams@helmholtz-muenchen.de \\ 2 Ludwig-Maximilians-Universität München, Biomedical Center, Physiological Genomics, Grosshaderner Str. 9, \\ 82152 Planegg-Martinsried, Germany \\ * Correspondence: therese.riedemann@med.uni-muenchen.de
}

\section{check for}

updates

Citation: Williams, R.H.;

Riedemann, T. Development,

Diversity, and Death of MGE-Derived

Cortical Interneurons. Int. J. Mol. Sci.

2021, 22, 9297. https://doi.org/

$10.3390 /$ ijms 22179297

Received: 22 July 2021

Accepted: 25 August 2021

Published: 27 August 2021

Publisher's Note: MDPI stays neutral with regard to jurisdictional claims in published maps and institutional affiliations.

Copyright: (c) 2021 by the authors. Licensee MDPI, Basel, Switzerland. This article is an open access article distributed under the terms and conditions of the Creative Commons Attribution (CC BY) license (https:// creativecommons.org/licenses/by/ $4.0 /)$.

\begin{abstract}
In the mammalian brain, cortical interneurons (INs) are a highly diverse group of cells. A key neurophysiological question concerns how each class of INs contributes to cortical circuit function and whether specific roles can be attributed to a selective cell type. To address this question, researchers are integrating knowledge derived from transcriptomic, histological, electrophysiological, developmental, and functional experiments to extensively characterise the different classes of INs. Our hope is that such knowledge permits the selective targeting of cell types for therapeutic endeavours. This review will focus on two of the main types of INs, namely the parvalbumin $\left(\mathrm{PV}^{+}\right)$ or somatostatin $\left(\mathrm{SOM}^{+}\right)$-containing cells, and summarise the research to date on these classes.
\end{abstract}

Keywords: GABA; cortical interneurons; somatostatin; parvalbumin; interneuron diversity; interneuron development

\section{Introduction}

The cortex of the mammalian brain is composed of two main neuronal groups: projection neurons and interneurons (INs) [1-8]. Projection neurons are cells whose axons extend from the region where they are located to other brain areas and/or to the spinal cord. In doing so, projection neurons facilitate communication between diverse areas of the central nervous system. In the neocortex, this communication is attributed to pyramidal cells and is virtually always activating, i.e., most often projection neurons excite postsynaptic neurons by releasing the neurotransmitter glutamate. INs on the other hand are classically defined by the fact that their axons reside locally, hence their original name 'short axon cell' as described by Ramon y Cajal. The population of cortical INs is highly diverse and composed of different classes of subtypes. INs can be either excitatory or inhibitory depending on the neurotransmitters released. Some interneuron (IN) types are cholinergic or monoaminergic but the vast majority of INs release the neurotransmitter $\gamma$-animo butyric acid (GABA), causing the activation of ionotropic or metabotropic GABA receptors. Activation of these pre or postsynaptic GABA receptors results in an increase in the chloride or potassium conductance, leading to a hyperpolarization of the cell and electrical silencing. Together, projection neurons enable global communication in the brain while cortical INs modulate this information flow. This modulation alters the strength of the message via different circuit motifs such as lateral inhibition, feedback, or feedforward inhibition/disinhibition. By directly modulating the excitability of pyramidal neurons, it is not surprising that dysfunctions in the GABAergic system and/or of GABAergic INs result in serious neurological and/or neuropsychiatric defects in human patients. As INs are composed of distinct cell classes, it is necessary to disentangle how the different IN classes assemble to control the correct dynamics of circuit excitability and to understand whether certain INs are more prone to disease than others. To date, it has been documented that different IN types display distinct innervation patterns onto pyramidal neurons to 
differentially affect their excitability. Moreover, most INs co-release neuropeptides when sufficiently activated, such as the vasoactive intestinal peptide, neuropeptide $Y$, or somatostatin, resulting in a sustained modulation of pyramidal cell output [9-11]. Due to this complexity, the mechanisms for an accurate assembly of neuron types within a given circuit to preserve its function requires both correct proportional expression of cell types and integrated synaptic compatibility. Therefore, the generation, maturation, and refinement of both main neuronal classes, as well as their respective subtypes, is a highly orchestrated developmental process. This review discusses the different INs classification schemes with a focus on parvalbumin $\left(\mathrm{PV}^{+}\right)$or somatostatin $\left(\mathrm{SOM}^{+}\right)$-containing INs, discussing the developmental ontology and selective features of these specific INs.

\section{Interneuron Classification Schemes}

\subsection{Morphology}

Traditionally, cortical INs have been characterised by a variety of somatodendritic morphologies (bipolar, multipolar, tufted, and bi-tufted) [12]. An expanded categorisation also considers the axonal ramifications and the synaptic innervation pattern of individual cells. According to the morphological classification scheme, 10 different cortical IN types have been distinguished, although several subtypes exist [13]. Some of the best studied morphological cell types in the rodent neocortex represent basket cells [14-20], chandelier cells [21-23], bipolar cells [12,24,25], neurogliaform cells [26-28], and Martinotti cells [25,29-32] (Figure 1). Most of these data are either derived from electron microscopy studies or from visualisation and reconstruction of patched cells in brain slices following electrophysiological recordings. An example of different morphological cell types found in the anterior cingulate mouse cortex is depicted in Figure 1. The axons of basket cells predominately reside within their home layer and typically form perisomatic 'basket' terminals with the soma and proximal dendrites of neighbouring cells. Basket cells classically make depressing synapses onto pyramidal neurons [33-35]. In contrast, axons from Martinotti cells spread across layers and ramify extensively in layer 1 (Figure 1). The preferred postsynaptic target of Martinotti cells, whereby they facilitate synapses [33-35], are distal dendrites of neighbouring pyramidal neurons. In addition, Martinotti cells also inhibit other INs. Neurogliaform cells are best characterised by their relatively small multipolar soma and dendritic tree (Figure 1), and by their remarkably high presynaptic bouton density $[28,36]$. As some of their presynaptic boutons are not associated with postsynaptic structures, it is suggested that these INs contribute to GABA volume transmission in the neocortex [37]. Neurogliaform cells inhibit all neurons within their sphere of influence, without any preference towards a specific cell type [38,39]. In summary, the morphology of INs reflects known functions of these cell types and permits the identification of presynaptic inputs and postsynaptic outputs. Nevertheless, morphological reconstructions from patched cells in brain slices are not foolproof and full reconstructions of complete neurite trees may not be possible because of the slice thickness or individual cell orientation in a slice. To overcome this limitation, great progress is being made using viral strategies in the living animal as well as through advanced microscopy techniques [1]. Sparse viral labelling of projection neurons in the cortex together with serial two-photon microscopy of optically cleared brain tissue allows for the near to complete visualisation and subsequent reconstruction of neuronal projections in the entire brain [1] and promotes our understanding of the connectivity of identified neurons. To date, morphological classifications represent a strong and valid experimental approach to defining INs classes, yet these classes are continuously reevaluated and redefined when combined with ultrastructural, electrophysiological, neurochemical, and/or transcriptomic data. 

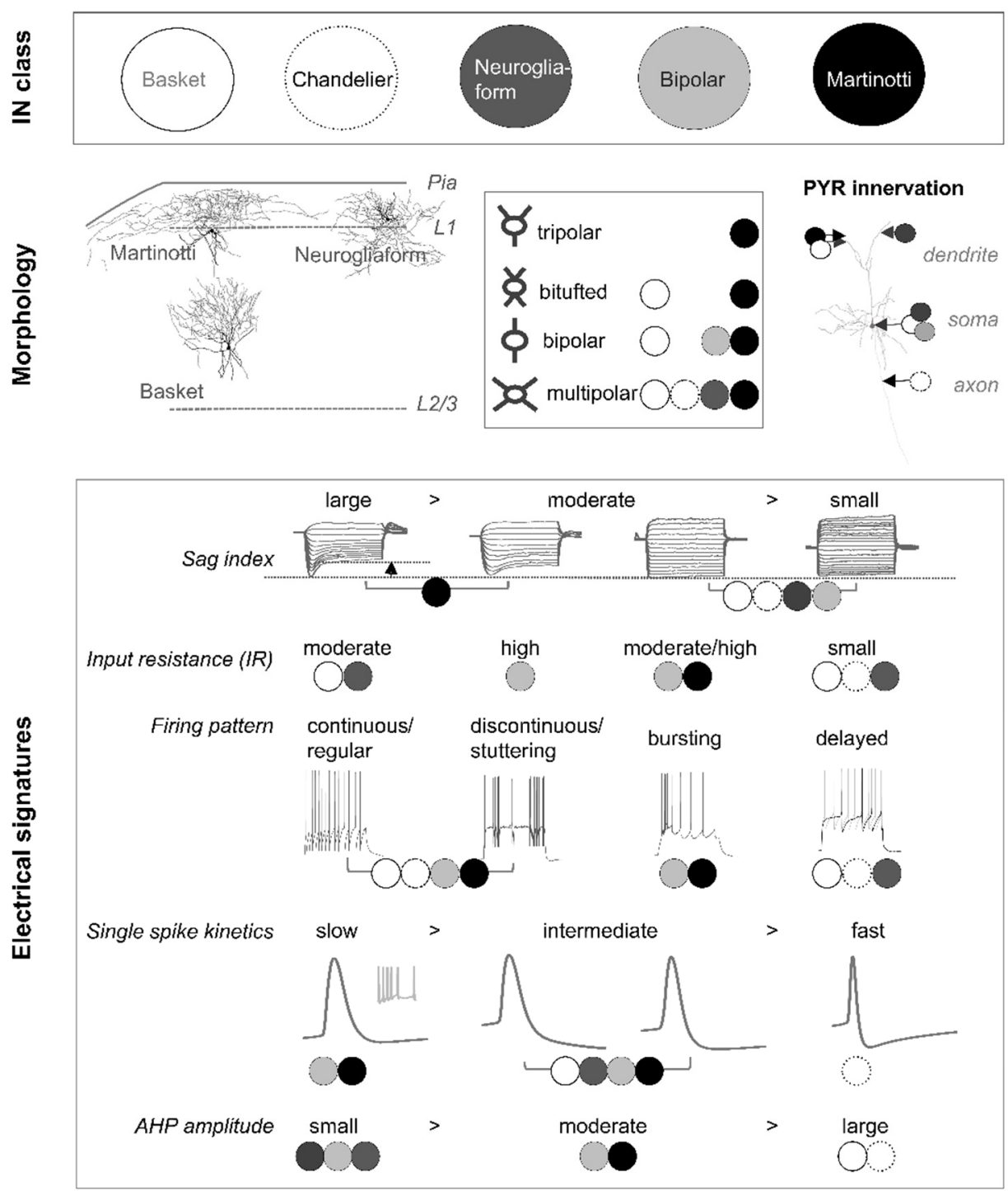

몰
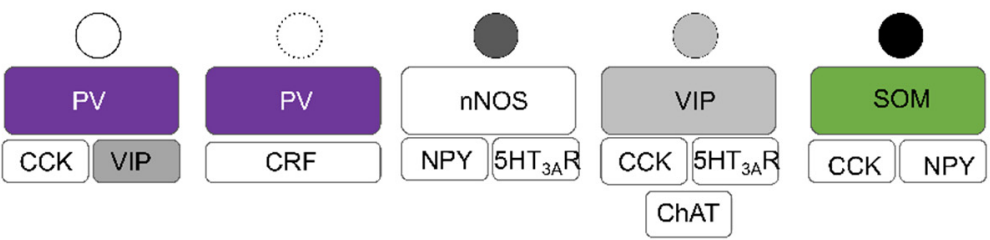

\begin{tabular}{|l|l|}
\hline \multicolumn{2}{|l|}{ Projecting cell } \\
\hline nNOS & NPY \\
\hline SOM & VIP \\
\hline
\end{tabular}

Figure 1. Overview of the major morphological interneuron types in the neocortex. Top: illustration of major morphological IN classes. Upper middle, left: representative reconstructions of Martinotti, neurogliaform, and basket cell type in the neocortex; middle: correlation of somatodendritic to morphological type; and right: schematic representation of preferred postsynaptic target of basket, Martinotti, neurogliaform, and bipolar cells on pyramidal cells (PYR). Lower middle: Schematic illustration of the electrical signatures of these four morphological IN types. Slow single spike kinetics are only observed in burst-spiking neurons. Bottom: expressed neurochemical markers in these IN subtypes. Abbreviations: AHP, afterhyperpolarisation; CCK, cholecystokinin; ChAT, choline acetyltransferase; L, cortical layer; nNOS, neuronal nitric oxide synthase; NPY, neuropeptide Y; PV, parvalbumin; PYR, pyramidal cell; SOM, somatostatin; VIP, vasoactive intestinal peptide; and $5 \mathrm{HT}_{3 \mathrm{~A}} \mathrm{R}, 5 \mathrm{HT}_{3 \mathrm{~A}}$ receptor. 


\subsection{Electrophysiology}

Historically, cell classes were derived based on three main electrophysiological features: (1) action potential discharge pattern, (2) single spike kinetics, and (3) passive membrane properties (resting membrane potential, input resistance, and cell capacitance). Based on firing patterns, all cortical INs can be assigned to one of four parent categories with each consisting of multiple subordinate groups. The parent categories distinguish cortical INs that respond to a suprathreshold depolarising current pulse with (1) continuous (or regular), (2) discontinuous (or stuttering), (3) burst-spiking, or (4) a delayed action potential discharge behaviour (Figure 1). The subordinate categories further distinguish between adapting, accommodating, irregular spiking, or accelerating IN types [13]. Furthermore, some INs are characterised by a low-threshold spike [40]. In contrast to the classification scheme based on morphological data, electrophysiological classification is associated with a high degree of variability and most morphological types show diverse action potential firing patterns. Nonetheless, a delayed action potential discharge pattern upon just suprathreshold current injection is typically associated with neurogliaform cells. Unfortunately, a similar correlation is not possible for most other IN types: however, basket cells and chandelier cells can best be characterised by their fast single spike kinetics and low input resistances (Figure 1). In contrast, Martinotti and bipolar cells exhibit intermediate single spike kinetics and moderate to high input resistances. In addition, analysis of the current-voltage relationship in morphological IN types reveals that large sag indices are typically observed in Martinotti cells. Therefore, the combined analysis of firing patterns [41] with other electrophysiological features such as intrinsic membrane properties, current-voltage relationships, single spike kinetics, and afterhyperpolarisation properties helps to sharpen the segregation of specific IN subtypes. Ideally, analysis of these properties should be combined with an analysis of pre and postsynaptic assessment for each morphological cell type.

\subsection{Neurochemistry}

GABAergic INs are currently grouped into three major classes according to their neurochemical expression profiles [42]. These classes are virtually non-overlapping and correspond to INs positive for the (1) parvalbumin $\left(\mathrm{PV}^{+}\right),(2)$ somatostatin $\left(\mathrm{SOM}^{+}\right)$, and (3) $5-\mathrm{HT}_{3 \mathrm{~A}}$ receptor $\left(5-\mathrm{HT}_{3 \mathrm{~A}} \mathrm{R}^{+}\right) .5-\mathrm{HT}_{3 \mathrm{~A}} \mathrm{R}^{+}$INs can in turn be divided into cells expressing either vasoactive intestinal peptide $\left(\mathrm{VIP}^{+}\right)$or Reelin (Reln, non-VIP INs) [43,44]. Moreover, despite these main classes, many INs coexpress a combination of different markers (including calcium-binding proteins, neuropeptides, and neurotransmitter receptors and enzymes), multiplying the number of neurochemical subtypes (Figure 1). As most INs belonging to one of the three neurochemical classes exhibit clear differences regarding electrophysiological and/or synaptic output properties, this neurochemical categorisation is a well-established and respected experimental approach to study IN function in specific cell types.

\subsection{Transcriptomics}

The availability of single-cell sequencing together with publicly available sequencing databases (e.g., https:/ / portal.brain-map.org/atlases-and-data/rnaseq) has significantly increased our understanding of cortical INs by enabling an in-depth analysis of individual neurons to evolve the traditional classification schemes [45-48]. According to transcriptomic profiling, cortical INs are clustered into 10 distinct classes and can further be sub-classified into more than 20 different subtypes. These distinct classes are characterised by the differential expression of neuropeptides, transcription factors, ion channels, neurotransmitter receptors, or calcium-binding proteins, among others. Interestingly, the designation of many IN classes mirrors their specific embryonic origin. However, it remains to be tested whether each transcriptomic subtype translates into a functional class within a given cortical circuit $[49,50]$. At present, there is not always full accordance between morphological, electrophysiological, and transcriptomic classifications, although in most 
cases there are good agreements $[45,46,51,52]$. While transcriptomic profiling is still in its scientific infancy compared to either classical morphological or electrophysiological approaches, it is apparent that an updated taxonomy of cortical interneuron subtypes is required.

\section{Laminar Distribution of Cortical Interneurons}

In the adult neocortex, $\mathrm{PV}^{+}$INs are the most frequent, comprising between $40-50 \%$ of all INs. The two other types, $\mathrm{SOM}^{+}$and $5-\mathrm{HT}_{3 \mathrm{~A}} \mathrm{R}^{+}\left(\mathrm{VIP}^{+}\right.$and non-VIP) INs, each contribute approximately $20-30 \%$ to the remaining proportion [42]. However, the relative proportions of each IN type to the overall population of GABAergic INs exhibit regionspecific differences: The relative density of $\mathrm{PV}^{+}$INs tends to be higher in the motor and somatosensory cortex, whereas for $\mathrm{VIP}^{+}$INs, the highest density is in the visual cortex [53]. In addition, each IN class has a unique laminar distribution pattern. $\mathrm{VIP}^{+} \mathrm{INs}_{\text {are }}$ preferably located in supragranular cortical layers [54-57]. Similarly, non-VIP INs, most of which are $\operatorname{Reln}^{+}, \mathrm{NPY}^{+}$, and/or nNOS ${ }^{+}$INs, are almost exclusively located in the superficial layers of the neocortex [58]. In contrast, the expression of $\mathrm{PV}^{+}$and $\mathrm{SOM}^{+} \mathrm{INs}$ tends to be greatest in layer 5 . INs present in cortical layer 1 are typically of the non-VIP type but a small fraction of $\mathrm{VIP}^{+}$and $\mathrm{SOM}^{+}$INs can also be observed in layer $1 . \mathrm{SOM}^{+}$INs present in layer 1 are preferably located at the border to layer 2 . No $\mathrm{PV}^{+}$INs are found in layer 1 (Figure 2).

A

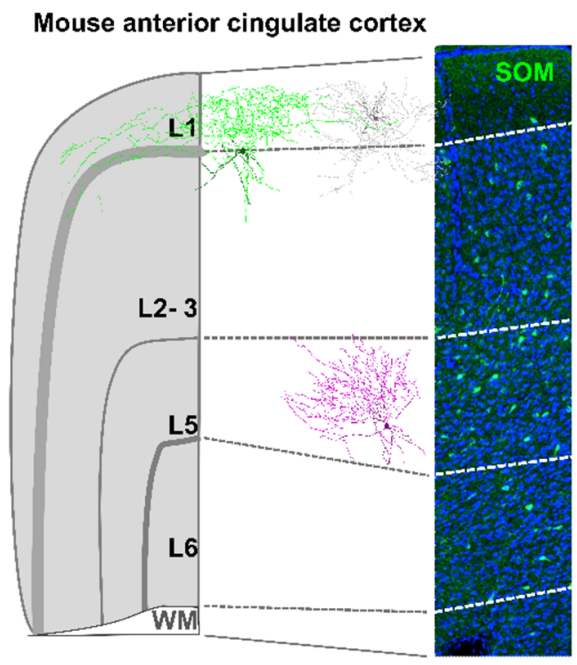

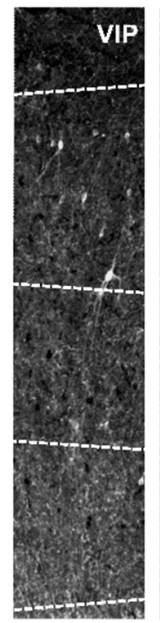

B

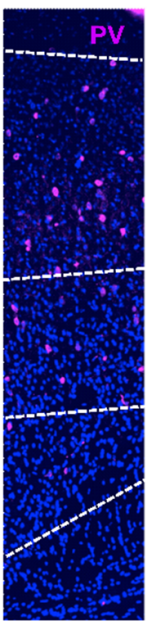

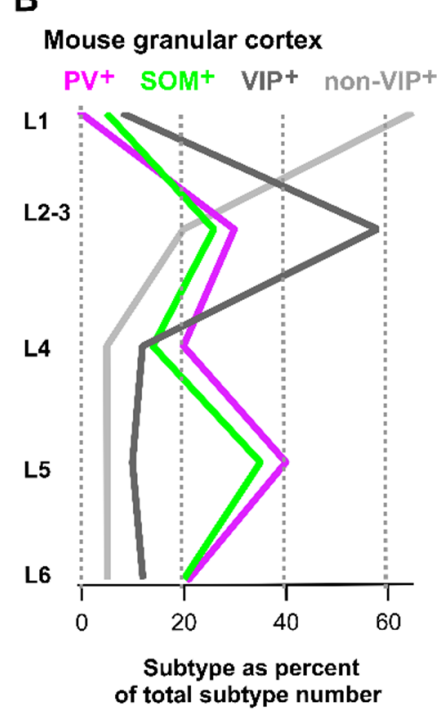

Figure 2. Laminar distribution profile of $\mathrm{PV}^{+}, \mathrm{SOM}^{+}, \mathrm{VIP}^{+}$, and non-VIP INs in the neocortex. (A) Left panel: schematic illustration of the mouse anterior cingulate cortex containing 1 Martinotti cell (green), 1 neurogliaform cell (grey), and 1 basket cell (magenta). Right Panel: confocal images (maximum intensity projections) of coronal sections of the mouse anterior cingulate cortex labelled for $\mathrm{SOM}^{+}$(left, green), $\mathrm{VIP}^{+}$(middle, white), and $\mathrm{PV}^{+}$(left, magenta) neurons. Nuclei were visualised with DAPI (blue) to identify cortical layers (left and right). (B) Diagram showing the relative fraction of $\mathrm{PV}^{+}$(magenta), $\mathrm{SOM}^{+}$(green), $\mathrm{VIP}^{+}$(dark grey), and non-VIP (light grey) INs as function of the cortical layer. PV and SOM expression can be observed in supra (L2/3) and infragranular (L5/6) layers, whereas that of VIP is restricted to supragranular layers.

\section{Origin and Development of $\mathrm{PV}^{+}$and $\mathrm{SOM}^{+}$Interneurons}

Around $90 \%$ of all cortical INs are derived from the ganglionic eminences (GE); $60 \%$ are derived from the medial GE (MGE) and 30\% are born in the caudal GE (CGE). The preoptic area (POA) produces the remaining $10 \%$ of cortical INs (Figure 3 ). 
A

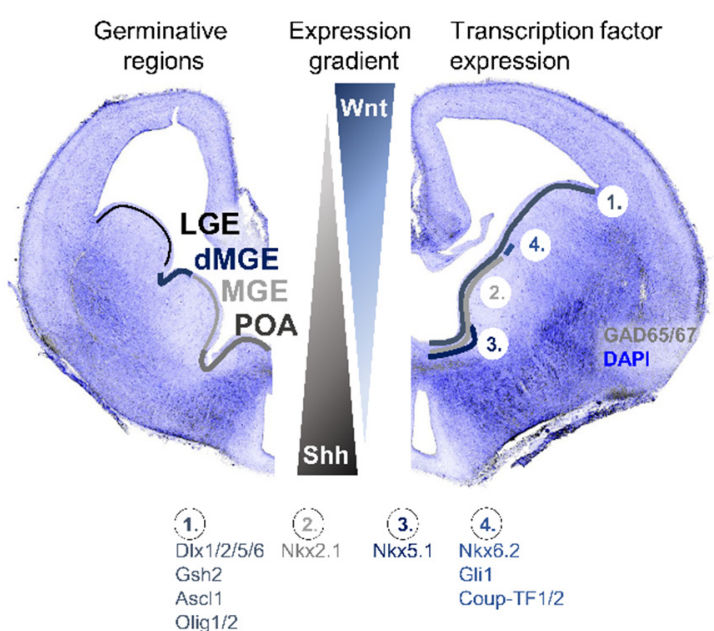

B
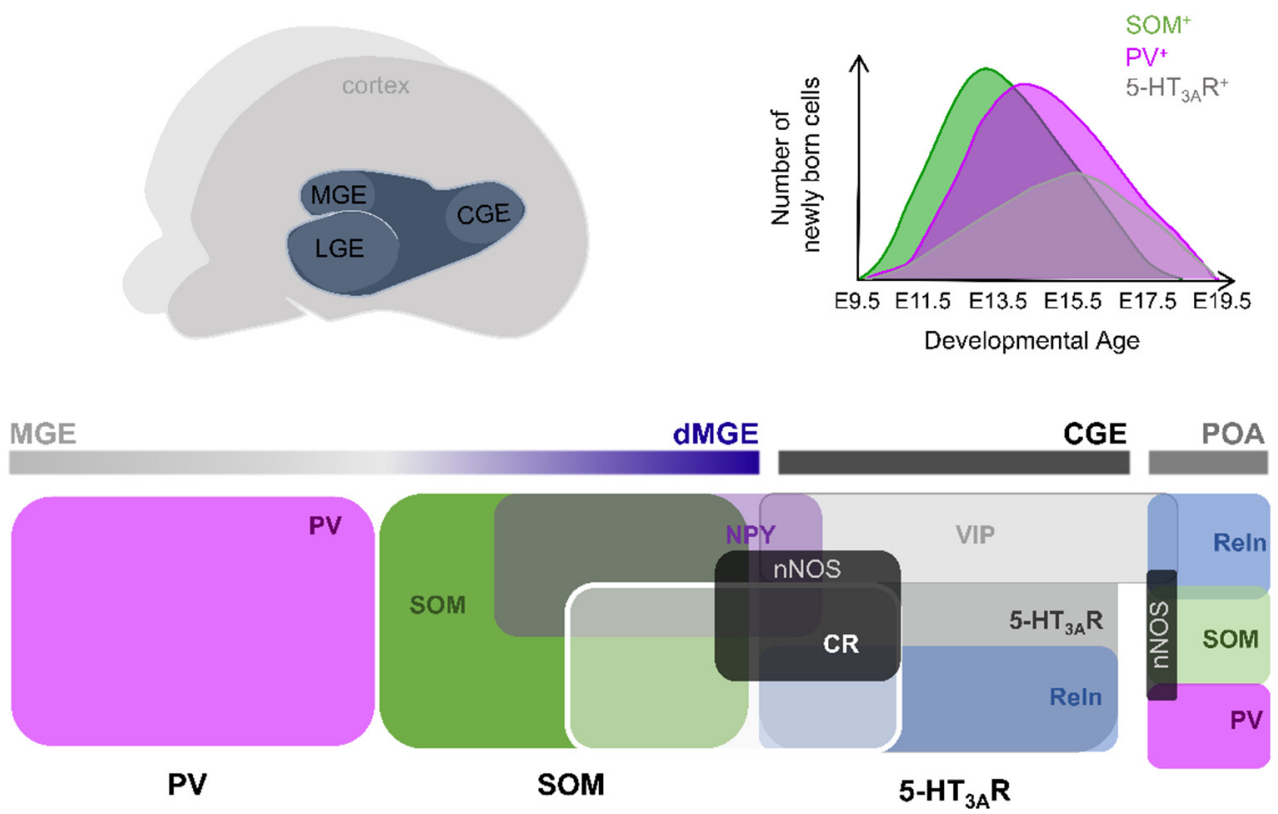

Figure 3. Embryonic origin and development of cortical interneurons. (A) Confocal image of a E14.5 coronal brain slice stained for GAD65/67 (grey) and DAPI (blue). The germinative regions (LGE, dMGE, MGE, and POA) are illustrated on the left hemisphere. The expression of distinct transcription factors is illustrated on the right hemisphere. The graded expression of Shh and Wnt is depicted in the middle. (B) Top, left panel: schematic representation of the brain with germinative regions illustrated in dark blue; and right panel: diagram showing the generation of $\mathrm{SOM}^{+}, \mathrm{PV}^{+}$, and 5-HT3AR ${ }^{+}$INs as a function of developmental age. Bottom: schematic of germinative regions in the embryonic brain and their relative contribution to classes of INs. The MGE gives preferentially rise to $\mathrm{PV}^{+}$and $\mathrm{SOM}^{+}$INs, whereas the CGE primarily produces $5-\mathrm{HT}_{3 \mathrm{~A}} \mathrm{R}^{+}$INs. The POA in turn produces a mixed population of GABAergic INs. MGE and CGE-derived INs typically coexpress a combination of different neurochemical markers, some of which are illustrated.

The germinative regions are divided into a ventricular zone (VZ) and a subventricular zone (SVZ), each hosting distinct neural precursors or progenitors. During early stages of cortical IN neurogenesis, most progenitor divisions occur at the ventricular surface. The SVZ develops at around E11 and progressively expands over time. By around E13-E14, the SVZ is the main site of progenitor proliferation and is composed of a great variety of progenitor types [59]. Electrophysiological recordings of neural progenitor cells and radial glial cells within the VZ showed that these cells are connected electrically via gap 
junctions well before synapse formation [60-64]. The number of electrically coupled cells becomes progressively smaller at later stages of development [60], suggesting that electrical synapses play a crucial role during progenitor proliferation [65] by coupling electrical activity to cell cycle transition. In addition, in vitro studies support the idea that neuronal or oligodendrocyte lineage is at least partly established by gap junctional coupling [66,67]. To date, it is unclear whether electrical coupling also affects IN subtype specification.

$\mathrm{SOM}^{+}$INs are thought to be generated from short neural precursors within the VZ of MGE. These MGE-derived $\mathrm{SOM}^{+} \mathrm{INs}$ and POA-derived INs represent the earliest born INs $[23,68,69] . \mathrm{PV}^{+}$INs are generated by intermediate progenitors of the MGE SVZ [70] and are the next born INs, finally followed by CGE-derived INs $[23,68,69]$ (Figure 3B).

\subsection{Morphogens and Cell Specificity}

Many studies suggest that pattern formation and fate specification of cortical INs is, at least partly, accomplished in the proliferative zones of the embryonic brain. Two hypotheses exist: (1) the generation of 'specific progenitors' in the VZ that give rise to specific IN subtypes or (2) the generation of 'cardinal progenitors' with a fluid identity [44,71]. The generation of these 'specific progenitors' requires the existence of local and chronological gradients of certain signalling molecules ('morphogens') and transcription factors that induce a specific cell fate in these progenitor cells. Such morphogens exhibit a topographical bias along the dorso-ventral or rostro-caudal axis of the GE [72-74], establishing a graded expression of downstream signalling molecules and transcription factors. There are four main protein morphogen families: Wnts, Sonic hedgehog (Shh), bone morphogenetic proteins (BMP), and Fibroblast growth factors (FGF).

Morphogens such as BMP or Wnts are secreted from the cortical hem while Sonic hedgehog (Shh) is secreted from the floor plate (Figure 3A). The location of the cortical hem adjacent to the MGE is such that BMP and Wnt secretion establishes a caudomedial (high) to ventrolateral (low) gradient along the MGE. Shh secretion from the floor plate results in a ventro-dorsal gradient. Conditional knockout animals, homotopic transplantation, and pharmacologic interventions have been instrumental in demonstrating the role of such morphogens in the fate specification of cortical INs [75-78]. Specifically, loss of Wnt signalling during embryonic development promotes a $\mathrm{PV}^{+}$phenotype and transplantation of labelled rostral (low Wnt levels) MGE cells at E12.5 into E13.5 unlabelled host embryos results in a strong bias towards $\mathrm{PV}^{+}$INs in the neocortex [75].

FGF promotes ventral and anterior telencephalic fates and indirectly inhibits BMP activity $[79,80]$. During embryonic brain development, FGF is secreted by the anterior forebrain and establishes a rostro-caudal and ventro-dorsal gradient to assist the specific graded expression patterns of transcription factors that result in the development of IN subtypes. Shh also acts as a positive feedforward molecule to drive secondary Shh signalling in the forebrain [81], in which it helps to maintain regional identity by inducing the expression of the homeobox transcription factor $\mathrm{Nk2}$ homeobox $(\mathrm{Nkx} 2.1)$ in the pallidal proliferative zone [76].

\subsection{Transcription Factors and Establishment of Regional Identity}

Transcription factors importantly contribute to cell specification and differentiation to generate cortical INs. Transcription factors mediating GABAergic IN fate are Ascl1, Dlx1/2, Dlx5/6, Gsh2, and Olig2 [82-87]. Regional identity (e.g., MGE vs. POA-derived INs) and subtype specification is then achieved by the localised expression of transcription factors or combinations thereof. There have been several key transcription factors identified: two of which are Nkx2.1 and Nkx6.2, produced from the Nk2 homeobox, whereas Nkx2.1 is expressed in the MGE and POA, and Nkx6.2 expression is limited to the dorsal aspect of the MGE $[88,89]$ (Figure 3A). Both are involved in shaping the cell types derived from the MGE. Nkx2.1 shares reciprocity with Shh and when active, maintains Shh expression [90,91]. It is involved in modifying regulatory elements to sculpt the identity of the resulting GABAergic INs from progenitors and specify regional identity. For example, Nkx2.1 loss- 
of-function studies in cells promoted the generation of LGE and CGE cell types at the expense of MGE-derived cells (e.g., cholinergic pallidal projection neurons), indicating a shift in the fate caused by altered lineage and region-specific genes [92-94] and suggesting that Nkx2.1 represses progenitor domains adjacent to the MGE [71]. Overall, Nkx2.1 acts as a master regulator of MGE progenitor identity. In comparison, Nkx6.2 preferentially regulates cell differentiation in precursors rather than in proliferating progenitors [88].

Additionally, Nkx2.1 affects cell specificity via the upstream induction of Lhx6 and Lhx8 Lim-homeobox genes responsible for the development of the globus pallidus [95]. LIM-homeobox genes are necessary for Lhx6 expression and together they enrich activating regulator elements to promote transcriptional activation and differentiation of MGEderived INs [95]. Lhx6 is then sufficient to drive the expression of Arx (aristaless-related homeobox) and the chemokine receptor 7 (Cxcr7) to generate $\mathrm{PV}^{+}$or $\mathrm{SOM}^{+} \mathrm{INs}$ [96-99]. Disruption of this Lhx6 pathway, such as via conditional knockout of the transcription factor Sp9 during embryonic development, results in significantly reduced cortical $\mathrm{PV}^{+}$ and $\mathrm{SOM}^{+}$IN numbers in the adult (P30) cortex.

Furthermore, the homeodomain transcription factor orthodenticle 2 (OTX2) is required for a rostro-ventral MGE identity and OTX2 knockout shifts the fate of the MGE-derived cells towards POA-derived cells [100].

The expression of transcription factors CoupTF-1 and CoupTF-2 is restricted to a continuous rostro-dorsal arc within the MGE VZ and the expression of both transcription factors becomes gradually limited to the dorsal MGE. In addition, CoupTF- $1 / 2$ is highly enriched in the CGE. Accordingly, Coup-TF1/2 is implicated in preferentially generating $\mathrm{SOM}^{+}$and CGE-derived cortical INs (Figure 3A) [101-103].

Similar to the limited expression of Nkx6.2 in the dorsal MGE, the expression of the Shh-responsive gene Gli1 is also restricted to the dorsal MGE and promotes the generation of $\mathrm{SOM}^{+}$INs $[104,105]$.

Given the graded expression of morphogens and transcription factors or combinations thereof, the germinative regions of the ganglionic eminences and of the preoptic area obtain regional identity and mostly produce distinct IN types. The MGE mainly gives rise to $\mathrm{PV}^{+}$ and $\mathrm{SOM}^{+} \mathrm{INs}$, whereas the CGE generates the majority of 5- $\mathrm{HT}_{3 \mathrm{~A}} \mathrm{R}^{+} \mathrm{INs}$ (Figure 3B). In contrast, the POA produces a diverse group of cortical INs comprising, amongst others, $\mathrm{PV}^{+}, \mathrm{SOM}^{+}$, and $\mathrm{VIP}^{+}$INs [68] (Figure 3B). Furthermore, transplantation of fluorescently labelled dMGE precursors resulted in grafted cells predominantly adopting a $\mathrm{SOM}^{+} \mathrm{IN}$ phenotype [106]. This indicated that most $\mathrm{SOM}^{+}$INs are generated from the dorsal aspect of the MGE (dMGE), whereas the MGE produces $\mathrm{PV}^{+}$INs [77]. Fate-mapping studies further revealed that $\mathrm{SOM}^{+}$INs coexpressing CR are preferentially generated in the dMGE, whereas those coexpressing NPY are primarily produced in the MGE [89]. As mentioned earlier, CGE-derived INs can further be subdivided into $\mathrm{VIP}^{+}$or non-VIP Reln ${ }^{+}$INs, both of which can coexpress nNOS and/or NPY [58,107] (Figure 3B).

It is not yet fully understood whether these different neurochemical IN types observed in the adult cortex are derived from specific progenitors within the germinative zone or whether mature neurochemical IN types are generated from cardinal progenitors. The latter are then sculpted into final specifications in the adult cortex depending on the cortical activity, connectivity, and function of a given IN within the cortical circuit.

\subsection{Interneuron Diversity from Specific versus Cardinal Progenitors}

In favour of the specific progenitor hypothesis is the finding that the generation of cortical INs follows an intrinsic schedule: first $\mathrm{SOM}^{+}$and then $\mathrm{PV}^{+} \mathrm{INs}$ are born from the MGE, indicating the generation of IN subtypes from specific progenitors [68,70]. This hypothesis is further supported by recent single-cell transcriptomics studies showing that MGE progenitors constitute a highly heterogenous group of cells [59,108,109], arguing for the existence of specific progenitors from which specific adult cortical IN types are derived.

Nevertheless, there appears a grey area whereby there is room for switching cell types between either $\mathrm{PV}^{+}$or $\mathrm{SOM}^{+}$phenotypes from a progenitor. Clonally related MGE 
progenitors give rise to $\mathrm{PV}^{+}$and $\mathrm{SOM}^{+} \mathrm{INs}$ [108,110-112], and conditional knockout of the tsc1 gene can shift the phenotype of $\mathrm{SOM}^{+}$INs towards a $\mathrm{PV}^{+}$IN phenotype [113]. These data suggest that cardinal progenitors are generated with a fluid identity. Considering that the majority of transcription factors occur in $\mathrm{SOM}^{+}$INs [71], it is postulated that $\mathrm{PV}^{+}$cell identity represents the 'default state' of MGE-derived INs and only the active suppression of this state, by induction of select transcription factors, permits a $\mathrm{SOM}^{+}$ IN phenotype. The difficulty in simulating the expression of time, location, and tissuedependent transcription factors in vitro is highlighted by only partial establishment of in vivo PV:SOM IN ratios from mouse embryonic stem cell-derived interneurons when transplanted into the somatosensory cortex [114-116].

To fully discern whether single progenitors allow for a fluid differentiation and maturation into different IN subtypes, single-cell spatial transcriptomics should be used [117,118]. This will enable a time-dependent analysis of single-cell specification from the same cell. Such an experiment should be combined with a functional readout to discern the role of transcriptomic subtypes in final cell physiology/morphology categorisation [50].

\subsection{Migration}

Newly generated cortical INs pause in the subventricular zone before migrating into the neocortex. A general rule is that earlier-born INs settle in the deeper cortical layers, while later-born cortical INs invade the more superficial layers. Around $50 \%$ of MGE-derived $\mathrm{SOM}^{+}$INs and a subgroup of $\mathrm{PV}^{+}$INs preferentially migrate along the superficial migratory stream [119]. Several migration cues are required to assist in the correct migration path to the neocortex and hence altered expression of these guidance cues is often associated with reduced numbers of cortical GABAergic INs [120-122]. In addition, ambient GABA and glutamate levels initially promote IN migration through activation of $\mathrm{GABA}_{\mathrm{A}}$ and AMPA/NMDA receptors [123,124]. GABA promotes migration by modifying intracellular calcium levels and the expression of the $\mathrm{K}^{+} / \mathrm{Cl}^{-}$cotransporter KCC2 [123-125]. Increased KCC2 levels inhibit IN motility so that the cell stops and matures in its given cortical location. INs that exhibit migratory defects, for example, due to lack of guidance cues and/or antagonised membrane receptors, preferentially undergo programmed cell death, which may ensure the perseveration of correct circuit assembly by physiologically healthy neurons [126].

\section{Postnatal Programmed Cell Death of MGE-Derived Interneurons}

The peak number of cortical GABAergic INs occurs at P5-7 and then cell numbers reduce by around 30\% within the next 10-12 days [127-129]. At the end of the second postnatal week, cortical IN numbers reach a steady state. These data suggest an active pruning of GABAergic INs to ensure an appropriate configuration is established. This pruning is via programmed cell death apoptosis and follows a strict temporal pattern [130]. A family of evolutionary conserved enzymes accomplishes apoptosis. These enzymes, known as caspases, function as cysteine proteases. Caspases are differentially recruited depending on whether cell death occurs in response to intrinsic or extrinsic factors. Extrinsic cell death is initiated by the activation of death receptors that in turn activate caspase- 8 . Intrinsic cell death is initiated by activation of caspase-9. Both signalling pathways converge onto the effector caspases-3 and/or caspases-7 that trigger the demise of the cell. For example, when E13.5 MGE-derived cells are grown in culture and then transplanted into the cortex, the peak of cell death occurs 15 days after transplantation, mimicking the timeline of the native in vivo IN cell fate [127].

\section{Control of Apoptosis}

Several signalling molecules can act as promoters or inhibitors of apoptosis. Proapoptotic proteins include the Bcl2-associated $\mathrm{X}$ protein (Bax) and Bcl2 antagonist/killer 1 (Bak), while $\mathrm{Bcl} 2$ and Blc2-like 1 (Blc-Xl) act as antiapoptotic factors. In the developing cortex, programmed IN cell death is Bax-dependent, is not modulated by neurotrophin signalling, 
and is modified by cell adhesion molecules of the protocadherin subgroup [127,131]. Interestingly, programmed cell death of inhibitory INs appears directly coupled to reduced excitatory activity and death of excitatory neurons. Indeed, it has been shown that (1) pyramidal cell death occurs before IN cell death; (2) P7 INs have significantly reduced neuronal activity $24 \mathrm{~h}$ before their death; and (3) (chemo)genetic pyramidal cell activation between $\mathrm{P} 5$ and $\mathrm{P} 8$ resulted in a significant increase in cortical $\mathrm{PV}^{+}$and $\mathrm{SOM}^{+} \mathrm{IN}$ numbers via reduced apoptotic IN events [132,133]. Equally, the rate of IN cell death is matched to that of pyramidal cell numbers to maintain a physiological excitatory-to-inhibitory neuron ratio in the neocortex.

Developmental apoptosis has region and cortical layer-specific differences [134]. More medial (motor cortex M1) superficial cortical layers have the highest numbers of induced cell death versus deep cortical layers and lateral cortical regions (somatosensory cortex S1). Coincidently, the numbers of cortical INs are highest in the somatosensory cortex compared to the motor cortex and are higher in the deeper cortical layers compared to the more superficial cortical layers (mean number of cells $/ \mathrm{mm}^{2}$ ) [53].

Intriguingly, premature birth leads to advanced neuronal cell death if cell death rates are compared as a function of post-conception age. Conversely, a delayed birth does not delay the rate of programmed cell death [135]. It is therefore suggested that programmed cell death follows an intrinsic developmental program that can be accelerated by an advanced birth. The underlying mechanisms of advancing programmed cell death are currently not well understood but are likely to be influenced by hormones.

\section{Postnatal Maturation of $\mathrm{SOM}^{+}$and $\mathrm{PV}^{+}$Interneurons}

\subsection{Onset of PV and SOM Expression in Neocortex}

By the first postnatal week, cortical IN migration is almost complete. Subsequently, the migrating distance of GABAergic interneurons is significantly reduced $[123,124]$ and cortical SOM protein expression increases. By the second postnatal week, cortical PV protein expression also occurs, resulting in the recognition of cortical $\mathrm{SOM}^{+}$and $\mathrm{PV}^{+}$ INs $[120,136-140]$. The chronological order of the protein expression of SOM and then $\mathrm{PV}$ appears to reflect the embryonic development of these two INs. In addition, there are also brain region-specific chronological expression patterns [54,57]. For example, auditory cortical tracing studies indicate that $\mathrm{PV}^{+}$IN numbers stabilize by around P35, whereas $\mathrm{SOM}^{+}$IN numbers increase until P145 in this region. In contrast, adult levels of $\mathrm{SOM}^{+}$and $\mathrm{PV}^{+}$INs in the visual cortex are already reached after the third postnatal week, suggesting cortex area-specific developmental differences [57]. It is unclear whether the development of specific neurochemical subtypes of $\mathrm{PV}^{+}$and/or $\mathrm{SOM}^{+}$IN types is accomplished by the time that SOM/PV levels reach a steady state in the neocortex or whether subtype differentiation continues until later developmental stages.

\subsection{Development of Connectivity}

Ex vivo electrophysiological recordings of postnatal $\mathrm{PV}^{+}$and $\mathrm{SOM}^{+} \mathrm{INs}$ demonstrate that both IN types acquire their final passive and active membrane properties after the second postnatal week [141-146]. Specifically, steady-state characteristics of passive membrane properties (resting membrane potential, input resistance, and somatic time constant) and maturation of single spike or action potential (AP) discharge properties of $\mathrm{SOM}^{+} \mathrm{INs}$ occur by P21 [141-143]. Similarly, PV ${ }^{+}$INs adopt their final electrophysiological phenotype by P21-P30 [144-148]. Spontaneous synaptic input onto $\mathrm{SOM}^{+} \mathrm{INs}$ increases with postnatal development $[141,142,144,146]$. Paired recordings between pyramidal neurons and $\mathrm{SOM}^{+}$ INs indicate increased connectivity strength with age $[142,144,149]$ and dual patch-clamp recordings between pairs of $\mathrm{SOM}^{+}$or pairs of $\mathrm{PV}^{+}$INs show increased electrical and chemical coupling probability with neuronal maturation, with a steady-state accomplished by P30 [141,144,147,150,151].

The synaptic relationship between $\mathrm{SOM}^{+}$or $\mathrm{PV}^{+} \mathrm{INs}$ onto pyramidal neurons has been best studied in the visual cortex. The former relationship is characterised by three 
main findings [142,151]: (1) it emerges around P6, (2) the connection probability increases with ongoing maturation, and (3) the strength of synaptic transmission appears linked to the eye-opening period of mice (around P14) [121,142,151]. In contrast, the synaptic connectivity of the latter relationship, once established, remains stable and the synaptic output is strengthened during the time of eye opening [151]. Moreover, the time course of $\mathrm{PV}^{+} \mathrm{IN}$ maturation and coupling to pyramidal cells is best reflected by the development of gamma oscillations in the neocortex [140]. Interestingly, sensory deprivation and experience affect the maturation of $\mathrm{PV}^{+}$and $\mathrm{SOM}^{+} \mathrm{INs}$, and the effects are more pronounced on $\mathrm{PV}^{+}$ Ins, suggesting that cortical activity levels, particularly if reduced, may contribute to the maturation of cortical INs and their connectivity [141,152-154].

Interneuronal activity levels during early postnatal development assist in the correct circuit assembly: (1) earlier-born $\mathrm{SOM}^{+}$INs within the infragranular layer act as a transient intermediate relay between the thalamus, $\mathrm{PV}^{+}$interneurons, and pyramidal neurons [155]; (2) early-born MGE-derived GABAergic INs, of which many become $\mathrm{SOM}^{+}$, act as cortical hub neurons that are able to generate recurrent network bursts [156]; (3) ablation of earlygenerated INs, $60 \%$ of which are $\mathrm{SOM}^{+}$, impairs the development of GABAergic synaptic inputs onto layer 5 pyramidal neurons [157]; and (4) $\mathrm{SOM}^{+}$INs play a paracrine role in the assembly of perisomatic inhibitory synapses by expressing Collagen XIX, an extracellular matrix protein that is necessary for perisomatic neuron assembly $[158,159]$. The specific loss of Collagen XIX in $\mathrm{SOM}^{+}$INs results in a dramatic loss of perisomatic nerve terminals onto pyramidal neurons [160].

To our knowledge, there are no studies investigating age-dependent spine formation in $\mathrm{SOM}^{+}$or $\mathrm{PV}^{+}$INs in the neocortex but this would be an interesting concept as spine formation and spine motility are linked to synaptic activity in both pyramidal and GABAergic INs [161-164]. In contrast to pyramidal cells, spine formation in SOM ${ }^{+}$INs and possibly also in $\mathrm{PV}^{+}$INs seems to be influenced by the expression of the polysialylated form of the neural adhesion molecule (PSA-NCAM) $[165,166]$. Therefore, given that spine formation in pyramidal cells and cortical INs is modulated by synaptic activity, albeit by partly diverging mechanisms, it could be postulated that the developmental profile of spine formation in $\mathrm{SOM}^{+}$and $\mathrm{PV}^{+}$INs mimics that of neocortical pyramidal cells. Accordingly, spine formation in cortical INs appears to be accomplished after electrophysiological maturation. Furthermore, spine formation in pyramidal cells is influenced by IN activity. Specifically, learning-induced spine formation in pyramidal cells of the motor cortex exhibits a higher dependence on $\mathrm{SOM}^{+} \mathrm{IN}$ activity compared to that of $\mathrm{PV}^{+}$INs and has direct effects on the learning of stereotyped movements. This corroborates the hypothesis that $\mathrm{SOM}^{+} \mathrm{INs}_{\text {play }}$ an active role in the arrangement of the synaptic circuitry [160,167].

While it is well established that activity and experience shape IN maturation, the underlying cellular mechanisms are only partially understood but likely include activitydependent signalling pathways that ultimately cause differential gene expression in subsets of INs [44]. These signalling pathways may be modulated by activity within the millisecondto-seconds range but also by diurnal or even seasonal activity [152].

In summary, electrophysiological recordings suggest that once $\mathrm{SOM}^{+}$and $\mathrm{PV}^{+} \mathrm{INs}$ have migrated to the cortex, their maturation is critically dependent on receiving synaptic input in order to successfully integrate into and modify the neuronal activity within a given cortical circuit.

\section{Properties of $\mathrm{PV}^{+}$INs}

\subsection{Morphology of $P V^{+} I N s$ and Expression of Neurochemical Markers}

$\mathrm{PV}^{+}$INs are the most distinguishable IN class with respect to their electrophysiological properties. The majority of $\mathrm{PV}^{+}$cells are either basket or chandelier cells. Both cell types are characterised by a round-to-oval shaped soma with, in general, a multipolar somatodendritic morphology (Figure 1). Most basket cells appear to share electrical and/or chemical synapses with each other $[168,169]$, while chandelier cells appear to only share electrical connections. Initial studies described basket cells as aspiny INs $[40,170,171]$; 
however, more recent studies suggest that the dendrites of certain basket cell subtypes are sparsely spiny with a mean spine density of around 1-2 per $10 \mu \mathrm{m}$ in the neocortex [172,173]. In contrast to basket cells, dendrites of chandelier cells are always aspiny (Figure 4). The axon of chandelier cells forms vertically oriented axon terminals, the so-called cartridges. These cartridges contain a string of presynaptic boutons that specifically innervate the axon initial segment of neighbouring pyramidal neurons, thus providing a powerful modulation of pyramidal cell output [32,174]. Worthy to note, not all chandelier cells express PV and it remains to be tested whether non-PV chandelier cells are functionally distinct $[175,176]$.

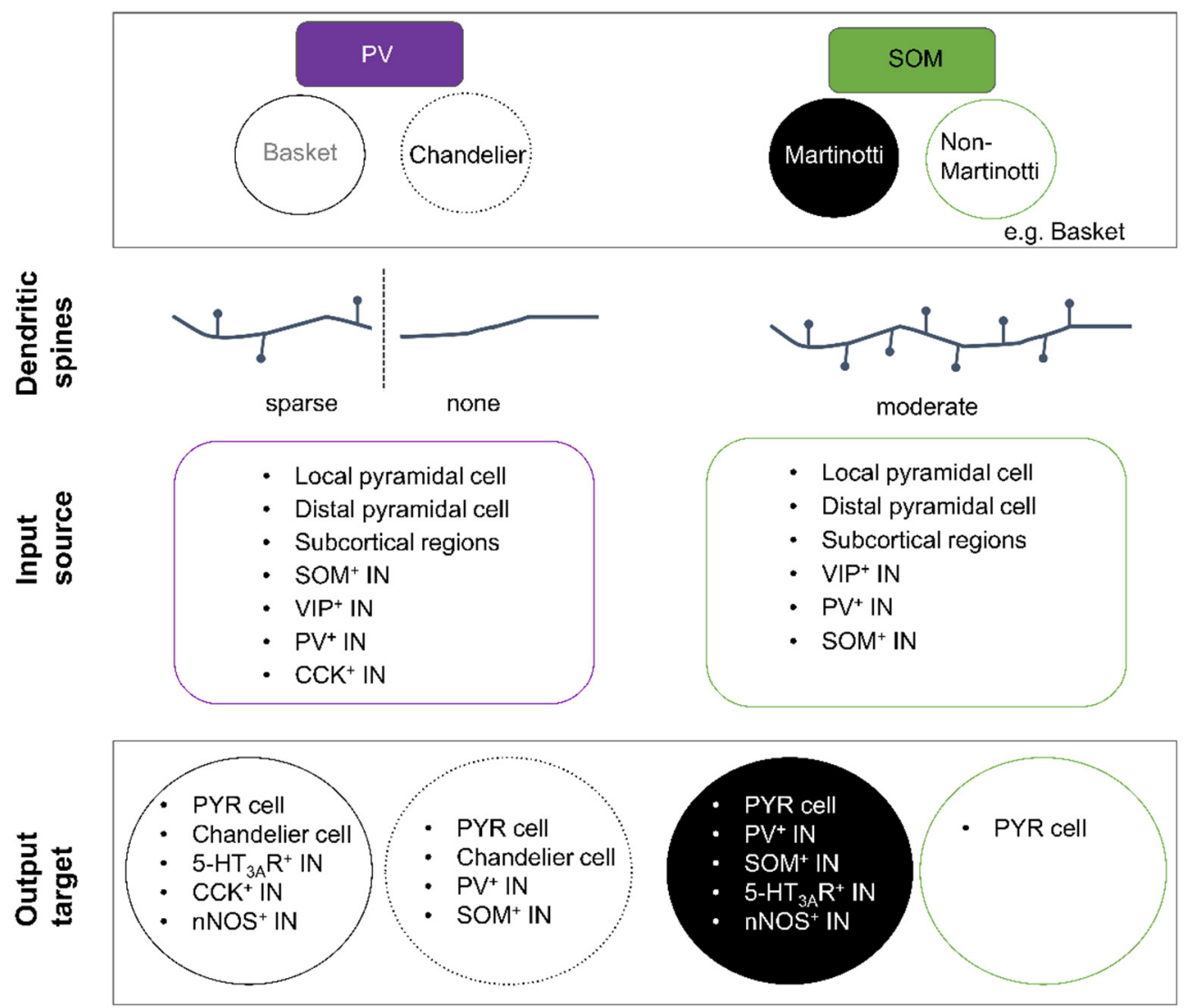

Figure 4. Overview of connectivity (presynaptic inputs and postsynaptic outputs) of neocortical $\mathrm{PV}^{+}$and $\mathrm{SOM}^{+}$INs. $\mathrm{PV}^{+}$INs are subdivided into basket and chandelier cells, and $\mathrm{SOM}^{+}$INs are subclassified into Martinotti and non-Martinotti cells. Dendritic spines can be found on $\mathrm{PV}^{+}$basket cells and on Martinotti and non-Martinotti cells. Dendrites of chandelier cells are always aspiny. The main input source onto any IN type represents pyramidal neurons but $\mathrm{PV}^{+}$and $\mathrm{SOM}^{+} \mathrm{INs}_{\text {also }}$ receive inhibitory inputs from other INs. Main output targets of any IN type are pyramidal cells followed by other IN types.

Typically, subtypes of $\mathrm{PV}^{+}$INs are known to coexpress the calcium-binding protein calbindin (CB), neuropeptide cholecystokinin (CCK), or glycoprotein reelin (Reln) $[6,46,56,177,178]$ If of chandelier morphology, DOCK7, which is essential for synaptic development, will be expressed [179,180], as well as the cell adhesion molecule Cadherin-6 [181] and VIP receptor 2 [182].

A small subpopulation of prefrontal $\mathrm{PV}^{+}$neurons are classed as long-range projection neurons as they project out of the cortex. One set innervates the nucleus accumbens and they elicit avoidance behaviour in mice [183]. Other long-range $\mathrm{PV}^{+}$populations in the auditory cortex have been shown to innervate the contralateral auditory cortex [184] or auditory striatum [185]. Interestingly, these long-range $\mathrm{PV}^{+}$neurons display distinct electrophysiological properties that distinguish them from the main class of $\mathrm{PV}^{+} \mathrm{INs}$ and may reflect a differential role in relaying cortical circuit function [184]. 


\subsection{Electrophysiological Properties of $P V^{+} I N s$}

$\mathrm{PV}^{+} \mathrm{INs}$ are often referred to as fast-spiking cells as the majority display fast spike kinetics with a pronounced and fast afterhyperpolarisation. Expression of voltage-gated potassium channels (Kv3.1 subtype) $[58,186,187]$ permits the cells to fire sustainably at high frequencies $(>200 \mathrm{~Hz})$, yet $\mathrm{PV}^{+}$INs have diverse firing patterns: The majority exhibit regular, delayed, or stuttering/discontinuous action potential firing. In addition, $\mathrm{PV}^{+} \mathrm{INs}$ typically display characteristic passive membrane properties that make them less excitable compared to $\mathrm{SOM}^{+}$INs (summarised in Figure 1).

\section{Properties of $\mathrm{SOM}^{+} \mathrm{INs}$}

$\mathrm{SOM}^{+}$INs represent a very diverse group of neurons with a myriad of morphological, electrophysiological, and neurochemical properties, resulting in many subtypes $[3,4,31,188]$. Nevertheless, $\mathrm{SOM}^{+}$INs remain distinguishable from $\mathrm{PV}^{+}$cells. Broadly speaking, $\mathrm{SOM}^{+}$ INs fall into two morphological categories: Martinotti (cortical layers $2 / 3$ and 5) and non-Martinotti cells (cortical layer 4 [188]) (Figure 4) [7].

\subsection{Morphology of SOM ${ }^{+}$INs and Expression of Neurochemical Markers}

Martinotti cells display a variety of somatodendritic morphologies and are easily recognised by their translaminar axon with dense arborisations that are always directed towards cortical layer 1 (see Figure 1). It is because of this extensive axonal arborisation that they are suggested to act as gate keepers of neocortical activity [189]. Postsynaptic targets are the proximal and distal dendrites of pyramidal neurons $[7,8,190,191]$, as well as neighbouring VIP ${ }^{+}$and $\mathrm{PV}^{+}$INs [192-194]. Within the somatosensory cortex, this type of $\mathrm{SOM}^{+}$INs share significant electrical coupling $[195,196]$.

Lastly, neurochemical profiles of $\mathrm{SOM}^{+} \mathrm{INs}$ are complex. Immunocytochemical studies can identify six distinct and non-overlapping neurochemical subgroups in the cingulate cortex alone [3]. In fact, only a minority of $\mathrm{SOM}^{+}$INs do not express another neuropeptide or calcium-binding protein. Most $\mathrm{SOM}^{+}$INs express a specific neuropeptide (such as NPY) or calcium binding protein, with calretinin and/or calbindin being the most common. Furthermore, preprodynorphin and reelin identifies another neurochemical subgroup of SOM $^{+}$INs $[178,197]$.

Non-Martinotti cells seem to represent the smaller fraction of the total population of $\mathrm{SOM}^{+} \mathrm{INs}[4,30,198]$ and are a morphologically heterogenous group. Some are basket cells [169] that resemble fast-spiking $\mathrm{PV}^{+}$INs [188]. Another subgroup consists of long-range GABAergic projection neurons [183,199-201]. These SOM ${ }^{+}$IN subtypes often coexpress nNOS, NPY, the substance P receptor [199,200], or the neuronal nicotinic receptor modulator Lypd6 [202]. The function of these $\mathrm{SOM}^{+}$projection neurons is unclear, yet one role appears to be auditory fear conditioning [203].

\subsection{Electrophysiological Properties of $\mathrm{SOM}^{+} \mathrm{INs}$}

Martinotti and non-Martinotti $\mathrm{SOM}^{+}$INs exhibit distinct electrophysiological signatures $[4,188]$. Martinotti cells display a continuous action potential discharge pattern but some are also reported to show burst-spiking, stuttering, or rarely delayed firing patterns (Figure 1) [4,30]. Non-Martinotti cells in turn [188] resemble fast-spiking INs with regard to their single spike properties and passive membrane properties. Low-threshold calcium spikes are exhibited by a significant proportion of infragranular $\mathrm{SOM}^{+}$INs $[30,40,196]$ but only by a minority of supragranular $\mathrm{SOM}^{+} \mathrm{INs}[4,25]$, which may be linked to cortical layer information processing.

\section{9. $\mathrm{PV}^{+}$and $\mathrm{SOM}^{+}$Interneuron Connectivity}

Granular and infragranular $\mathrm{PV}^{+}$INs receive strong inputs from thalamic afferents and function as feed-forward inhibitors of pyramidal cells that likewise receive strong excitatory input from thalamic afferents, thereby enhancing the temporal fidelity of pyramidal cell responsiveness. Supragranular $\mathrm{PV}^{+}$INs receive inputs from excitatory corticocortical affer- 
ents as well as from neighbouring pyramidal neurons (Figure 4) [149,204-206], indicating that $\mathrm{PV}^{+}$INs not only provide feedforward but also feedback inhibition, preferentially targeting the proximal dendrites and the soma of pyramidal neurons. $\mathrm{PV}^{+} \mathrm{INs}$ are known to innervate Chandelier cells, $\mathrm{VIP}^{+}, \mathrm{CCK}^{+}, \mathrm{nNOS}^{+}$, and SOM${ }^{+}$INs $[194,207,208]$. In contrast, $\mathrm{SOM}^{+}$INs mostly receive excitatory inputs from neighbouring pyramidal neurons and weaker inputs from thalamic and corticocortical afferents, in turn preferentially inhibiting the distal and proximal dendrites of not only pyramidal cells but also $\mathrm{PV}^{+}, \mathrm{nNOS}^{+}$, and VIP $^{+}$INs (Figure 4) $[192,193,208-213]$. It is postulated that SOM ${ }^{+}$INs are "ideally located within the cortical circuit to modulate sensory integration" [214] and provide not only lateral/feedback but also feedforward inhibition.

Activation of cortical afferents usually induces depressing responses in $\mathrm{PV}^{+} \mathrm{INs}_{\text {, }}$ whereas those onto $\mathrm{SOM}^{+}$INs are typically facilitating [33-35,215-217]. The inhibitory input onto $\mathrm{PV}^{+}$INs largely derives from $\mathrm{SOM}^{+}, \mathrm{VIP}^{+}$, and $\mathrm{CCK}^{+} \mathrm{INs}_{\text {. }} \mathrm{PV}^{+}$INs typically display electrical coupling with other $\mathrm{PV}^{+}$INs and chandelier cells [194,218-222]. In contrast, $\mathrm{SOM}^{+} \mathrm{INs}$ primarily receive inhibitory inputs from layer 1 INs, many of which are $\mathrm{VIP}^{+}$INs [211]. Comparing the synaptic input frequency between supragranular $\mathrm{PV}^{+}$ and $\mathrm{SOM}^{+} \mathrm{INs}, \mathrm{PV}^{+}$INs seem to receive excitatory and inhibitory synaptic inputs with a higher frequency $(2-40 \mathrm{~Hz}$ vs. $1-10 \mathrm{~Hz})[4,145,223-228]$. The larger synaptic input onto $\mathrm{PV}^{+}$INs in comparison to $\mathrm{SOM}^{+}$INs might reflect their differential recruitment: it was recently shown that $\mathrm{PV}^{+}$INs of the somatosensory cortex are preferentially recruited by long-range excitatory inputs [213].

In addition, the activity of both IN types is modulated by afferents from subcortical regions such as the nucleus raphé or the basal forebrain. Optogenetic stimulation of the latter strongly modulates the activity of prefrontal $\mathrm{nNOS}^{+} / \mathrm{SOM}^{+} \mathrm{INs}$ and pharmacological activation of acetylcholine receptors has been shown to predominantly excite $\mathrm{PV}^{+}$and $\mathrm{SOM}^{+}$INs $[229,230]$.

\section{Functional Implications for $\mathrm{PV}^{+}$and $\mathrm{SOM}^{+}$INs 10.1. $P V^{+}$INs}

From a functional perspective, neocortical $\mathrm{PV}^{+}$INs are involved in maintaining cortical 'up' states, high gamma and ripple oscillations in the upper cortical layers, and in suppressing beta oscillations in the deeper cortical layers [140,231,232] during wakefulness. During sleep, cortical excitability is generally decreased $[233,234]$ and $\mathrm{PV}^{+}$INs show a distinct activity pattern across different sleep stages and may contribute to memory consolidation during sleep. In addition, while $\mathrm{PV}^{+} \mathrm{IN}$ activity decreases during slow wave sleep (SWS), it increases during rapid eye movement (REM) sleep. Therefore $\mathrm{PV}^{+}$INs are thought to provide increased cortical inhibition during REM sleep $[235,236]$. It has been further suggested that $\mathrm{PV}^{+}$IN activity levels during wakefulness and sleep are accompanied by diurnal changes in the levels of perineuronal nets (PNNs) surrounding $\mathrm{PV}^{+}$INs and by an increase in the PV protein itself [237]. Nevertheless, it would be beneficial to monitor both PNN and PV levels during different sleep stages and then correlate those directly to $\mathrm{PV}^{+}$ IN activity to really understand the functional significance of how PNNs may contribute to $\mathrm{PV}^{+}$IN activity and excitability.

Selective inactivation of $\mathrm{PV}^{+}$INs results in working memory impairments, cognitive deficits, and reduced behavioural flexibility and sociability in mice [238-240]. These data reflect a functional importance of $\mathrm{PV}^{+}$INs for information processing.

\section{2. $\mathrm{SOM}^{+} \mathrm{INS}$}

Neocortical $\mathrm{SOM}^{+}$INs are implicated in sound habituation, the reversal of sound habituation [241], stimulus-specific adaptation [242,243], centre-surround modulation [244], and fear conditioning [203]. In addition, a role for $\mathrm{SOM}^{+} \mathrm{INs}$ in learning and memory and in higher cognitive function has been attributed: (1) activity of $\mathrm{SOM}^{+}$INs regulates the spine density of pyramidal cells [167]; (2) $\mathrm{SOM}^{+}$INs are preferentially active during the delay period of a working memory task [245]; (3) optogenetic activation of $\mathrm{SOM}^{+}$INs suppresses 
the delay period and impairs behavioural performance [240]; (4) SOM ${ }^{+}$INs are crucial for affective state discrimination [239]; and (5) social fear expression is dependent on activity of $\mathrm{SOM}^{+}$INs and $\mathrm{SOM}^{+}$inactivation reduces social fear behaviour [246,247]. It could be shown that gamma rhythm in the visual cortex (V1) is dependent on $\mathrm{SOM}^{+}\left(\right.$and $\mathrm{PV}^{+}$) INs activity [248]. Similarly, $\mathrm{SOM}^{+}$projection neurons of the septo-hippocampal circuit play a role in the generation of rhythmic oscillations in the hippocampus [249-251] and the activity of $\mathrm{SOM}^{+}$INs of the basal forebrain correlates with gamma band activity within the same cortex area [252]. $\mathrm{SOM}^{+}$INs display a sleep stage-dependent activity profile and exhibit increased activity during SWS, suggesting that pyramidal cell excitability during SWS is mainly controlled by $\mathrm{SOM}^{+}$INs [235].

\subsection{Neurodevelopmental Disorders of $\mathrm{PV}^{+}$and/or $\mathrm{SOM}^{+}$IN Function}

Behaviour is defined as "internally coordinated responses (actions or inactions) of whole living organisms (individuals or groups) to internal and/or external stimuli, excluding responses more easily understood as developmental changes" [253]. Every organism must thus be able to respond to external and internal stimuli in a context-dependent manner. Therefore, sensory information processing and integration must be stimulated or suppressed to induce a relevant and beneficial behavioural response. As mentioned earlier, GABAergic INs modulate the output signal of pyramidal neurons and help to heighten the contrast of processed information by different circuit motifs of inhibition. In doing so, GABAergic INs play an important role in suppressing or allowing sensory information processing to induce habituation or sensitisation to internal or external stimuli [238-244]. As such, it is not surprising that alterations in $\mathrm{PV}^{+}$or $\mathrm{SOM}^{+}$IN numbers or cortical displacement of $\mathrm{PV}^{+}$and /or $\mathrm{SOM}^{+} \mathrm{INs}$ are accompanied by unphysiological behavioural responses in animals and human patients that can manifest as mood disorders, working memory disorders, autism spectrum disorders, bipolar disorders, or cognitive impairments [254-263]. In addition, many of these disorders are accompanied by a higher incidence of epileptic seizures in animals and/or human patients [92,264-266].

\section{Conclusions}

The assembly of neural circuits is a multi-level process that is initiated by the birth of neurons and is accomplished by their correct positioning and wiring within a given cortical circuit. Adjustments to neural circuits occur continuously throughout life as do behavioural adaptations to experience. Proper network function necessitates that the correct number and types of neurons communicate with each other in a context-dependent manner. On a general scale, this means that a precise number of excitatory and inhibitory neurons are recruited to maintain a physiological network activity level. This means that excess numbers of neurons must be eliminated from the circuit and that this recruitment must also consider the subtype of the neuron that is being incorporated into a given neural circuit. Cortical INs are composed of diverse groups of cells, many of which are in turn made up of subgroups and further subordinates. These groups differ in their morphological, electrophysiological, neurochemical, and functional properties. It appears that subtype specificity in cortical INs is primarily organised by lineage but neuronal activity can have an impact on the IN phenotype. However, the details of how $\mathrm{PV}^{+}$and/or $\mathrm{SOM}^{+}$INs differentiate from the MGE during their development into the final phenotype, and whether subgroups of INs play a functional role, are only beginning to be understood.

Author Contributions: Writing—original draft preparation, T.R.; writing-review and editing, R.H.W. \& T.R.; visualization, R.H.W. \& T.R. All authors have read and agreed to the published version of the manuscript.

Funding: T.R. is funded by Friedrich-Baur Stiftung 04/21, R.H.W. is supported by ERC StG 715933 iNAPS and Helmholtz Zentrum Muenchen.

Institutional Review Board Statement: Not applicable. 
Informed Consent Statement: Not applicable.

Data Availability Statement: Not applicable.

Acknowledgments: T.R. would like to thank Gabi Horn for her excellent technical assistance.

Conflicts of Interest: The authors declare no conflict of interest.

\section{References}

1. Winnubst, J.; Bas, E.; Ferreira, T.A.; Wu, Z.; Economo, M.N.; Edson, P.; Arthur, B.J.; Bruns, C.; Rokicki, K.; Schauder, D.; et al. Reconstruction of 1000 Projection Neurons Reveals New Cell Types and Organization of Long-Range Connectivity in the Mouse Brain. Cell 2019, 179, 268-281.e13. [CrossRef] [PubMed]

2. McGarry, L.M.; Packer, A.M.; Fino, E.; Nikolenko, V.; Sippy, T.; Yuste, R. Quantitative classification of somatostatin-positive neocortical interneurons identifies three interneuron subtypes. Front. Neural Circuits 2010, 4, 12. [CrossRef]

3. Riedemann, T.; Schmitz, C.; Sutor, B. Immunocytochemical heterogeneity of somatostatin-expressing GABAergic interneurons in layers II and III of the mouse cingulate cortex: A combined immunofluorescence/design-based stereologic study. J. Comp. Neurol. 2015, 524, 2281-2299. [CrossRef] [PubMed]

4. Riedemann, T.; Straub, T.; Sutor, B. Two types of somatostatin-expressing GABAergic interneurons in the superficial layers of the mouse cingulate cortex. PLoS ONE 2018, 13, e0200567. [CrossRef]

5. Klausberger, T.; Somogyi, P. Neuronal Diversity and Temporal Dynamics: The Unity of Hippocampal Circuit Operations. Science 2008, 321, 53-57. [CrossRef]

6. Markram, H.; Toledo-Rodriguez, M.; Wang, Y.; Gupta, A.; Silberberg, G.; Wu, C. Interneurons of the neocortical inhibitory system. Nat. Rev. Neurosci. 2004, 5, 793-807. [CrossRef]

7. Tremblay, R.; Lee, S.; Rudy, B. GABAergic Interneurons in the Neocortex: From Cellular Properties to Circuits. Neuron 2016, 91, 260-292. [CrossRef]

8. Riedemann, T. Diversity and Function of Somatostatin-Expressing Interneurons in the Cerebral Cortex. Int. J. Mol. Sci. 2019, 20, 2952. [CrossRef]

9. Riedemann, T.; Sutor, B. Long-lasting actions of somatostatin on pyramidal cell excitability in the mouse cingulate cortex. Neurosci. Lett. 2019, 698, 217-223. [CrossRef]

10. Hu, B.; Cilz, N.I.; Lei, S. Somatostatin depresses the excitability of subicular bursting cells: Roles of inward rectifier K+channels, KCNQ channels and Epac. Hippocampus 2017, 27, 971-984. [CrossRef] [PubMed]

11. Galarraga, E.; Vilchis, C.; Tkatch, T.; Salgado, H.; Tecuapetla, F.; Perez-Rosello, T.; Perez-Garci, E.; Hernández-Echeagaray, E.; Surmeier, D.; Bargas, J. Somatostatinergic modulation of firing pattern and calcium-activated potassium currents in medium spiny neostriatal neurons. Neuroscience 2007, 146, 537-554. [CrossRef] [PubMed]

12. Cauli, B.; Zhou, X.; Tricoire, L.; Toussay, X.; Staiger, J.F. Revisiting enigmatic cortical calretinin-expressing interneurons. Front. Neuroanat. 2014, 8, 52. [CrossRef]

13. The Petilla Interneuron Nomenclature Group (PING) Petilla terminology: Nomenclature of features of GABAergic interneurons of the cerebral cortex. Nat. Rev. Neurosci. 2008, 9, 557-568. [CrossRef] [PubMed]

14. Defelipe, J.; Fairén, A. A type of basket cell in superficial layers of the cat visual cortex. A Golgi-electron microscope study. Brain Res. 1982, 244, 9-16. [CrossRef]

15. Defelipe, J.; Hendry, S.; Jones, E. A correlative electron microscopic study of basket cells and large gabaergic neurons in the monkey sensory-motor cortex. Neuroscience 1986, 17, 991-1009. [CrossRef]

16. Freund, T.F.; Martin, K.A.C.; Smith, A.D.; Somogyi, P. Glutamate decarboxylase-immunoreactive terminals of Golgi-impregnated axoaxonic cells and of presumed basket cells in synaptic contact with pyramidal neurons of the cat's visual cortex. J. Comp. Neurol. 1983, 221, 263-278. [CrossRef] [PubMed]

17. Wang, Y.; Gupta, A.; Toledo-Rodriguez, M.; Wu, C.Z.; Markram, H. Anatomical, Physiological, Molecular and Circuit Properties of Nest Basket Cells in the Developing Somatosensory Cortex. Cereb. Cortex 2002, 12, 395-410. [CrossRef] [PubMed]

18. Kisvárday, Z.F.; Beaulieu, C.; Eysel, U.T. Network of GABAergic large basket cells in cat visual cortex (area 18): Implication for lateral disinhibition. J. Comp. Neurol. 1993, 327, 398-415. [CrossRef]

19. Martin, K.; Somogyi, P.; Whitteridge, D. Physiological and morphological properties of identified basket cells in the cat's visual cortex. Exp. Brain Res. 1983, 50, 193-200. [CrossRef]

20. Somogyi, P.; Soltész, I. Immunogold demonstration of GABA in synaptic terminals of intracellularly recorded, horseradish peroxidase-filled basket cells and clutch cells in the cat's visual cortex. Neuroscience 1986, 19, 1051-1065. [CrossRef]

21. DeFelipe, J.; Hendry, S.H.C.; Jones, E.G.; Schmechel, D. Variability in the terminations of GABAergic chandelier cell axons on initial segments of pyramidal cell axons in the monkey sensory-motor cortex. J. Comp. Neurol. 1985, 231, 364-384. [CrossRef] [PubMed]

22. Marín-Padilla, M. The chandelier cell of the human visual cortex: A Golgi study. J. Comp. Neurol. 1987, 256, 61-70. [CrossRef]

23. Inan, M.; Anderson, S.A. The chandelier cell, form and function. Curr. Opin. Neurobiol. 2014, 26, 142-148. [CrossRef] [PubMed]

24. Peters, A.; Harriman, K.M. Enigmatic bipolar cell of rat visual cortex. J. Comp. Neurol. 1988, 267, 409-432. [CrossRef]

25. Kawaguchi, Y.; Kubota, Y. Physiological and morphological identification of somatostatin- or vasoactive intestinal polypeptidecontaining cells among GABAergic cell subtypes in rat frontal cortex. J. Neurosci. 1996, 16, 2701-2715. [CrossRef] 
26. Povysheva, N.V.; Zaitsev, A.V.; Kröner, S.; Krimer, O.A.; Rotaru, D.C.; Gonzalez-Burgos, G.; Lewis, D.A.; Krimer, L.S. Electrophysiological Differences Between Neurogliaform Cells From Monkey and Rat Prefrontal Cortex. J. Neurophysiol. 2007, 97, 1030-1039. [CrossRef]

27. Naegele, J.; Katz, L.C. Cell surface molecules containing N-acetylgalactosamine are associated with basket cells and neurogliaform cells in cat visual cortex. J. Neurosci. 1990, 10, 540-557. [CrossRef]

28. Wadiche, L.; McBain, C.J. Neurogliaform cells in cortical circuits. Nat. Rev. Neurosci. 2015, 16, 458-468. [CrossRef] [PubMed]

29. Marín-Padilla, M. The Pyramidal Cell and its Local-Circuit Interneurons: A Hypothetical Unit of the Mammalian Cerebral Cortex. J. Cogn. Neurosci. 1990, 2, 180-194. [CrossRef]

30. Wang, Y.; Toledo-Rodriguez, M.; Gupta, A.; Wu, C.; Silberberg, G.; Luo, J.; Markram, H. Anatomical, physiological and molecular properties of Martinotti cells in the somatosensory cortex of the juvenile rat. J. Physiol. 2004, 561, 65-90. [CrossRef]

31. Zhou, X.; Mansori, I.; Fischer, T.; Witte, M.; Staiger, J.F. Characterizing the morphology of somatostatin-expressing interneurons and their synaptic innervation pattern in the barrel cortex of the GFP-expressing inhibitory neurons mouse. J. Comp. Neurol. 2019, 528, 244-260. [CrossRef]

32. Kawaguchi, Y.; Kubota, Y. Neurochemical features and synaptic connections of large physiologically-identified GABAergic cells in the rat frontal cortex. Neuroscience 1998, 85, 677-701. [CrossRef]

33. Losonczy, A.; Zhang, L.; Shigemoto, R.; Somogyi, P.; Nusser, Z. Cell type dependence and variability in the short-term plasticity of EPSCs in identified mouse hippocampal interneurones. J. Physiol. 2002, 542, 193-210. [CrossRef] [PubMed]

34. Pala, A.; Petersen, C.C. In Vivo Measurement of Cell-Type-Specific Synaptic Connectivity and Synaptic Transmission in Layer 2/3 Mouse Barrel Cortex. Neuron 2014, 85, 68-75. [CrossRef] [PubMed]

35. Hu, H.; Agmon, A. Differential Excitation of Distally versus Proximally Targeting Cortical Interneurons by Unitary Thalamocortical Bursts. J. Neurosci. 2016, 36, 6906-6916. [CrossRef]

36. Earmstrong, C.; Ekrook-Magnuson, E.; Esoltesz, I. Neurogliaform and Ivy Cells: A Major Family of nNOS Expressing GABAergic Neurons. Front. Neural Circuits 2012, 6, 23. [CrossRef] [PubMed]

37. Oláh, S.; Füle, M.; Komlósi, G.; Varga, C.; Báldi, R.; Barzó, P.; Tamás, G. Regulation of cortical microcircuits by unitary GABAmediated volume transmission. Nature 2009, 461, 1278-1281. [CrossRef]

38. Jiang, X.; Shen, S.; Cadwell, C.; Berens, P.; Sinz, F.; Ecker, A.S.; Patel, S.C.; Tolias, A.S. Principles of connectivity among morphologically defined cell types in adult neocortex. Science 2015, 350, aac9462. [CrossRef]

39. Simon, A.; Oláh, S.; Molnar, G.; Szabadics, J.; Tamás, G. Gap-Junctional Coupling between Neurogliaform Cells and Various Interneuron Types in the Neocortex. J. Neurosci. 2005, 25, 6278-6285. [CrossRef]

40. Kawaguchi, Y.; Kubota, Y. Correlation of physiological subgroupings of nonpyramidal cells with parvalbumin- and calbindinD28kimmunoreactive neurons in layer V of rat frontal cortex. J. Neurophysiol. 1993, 70, 387-396. [CrossRef]

41. Komendantov, A.O.; Venkadesh, S.; Rees, C.L.; Wheeler, D.W.; Hamilton, D.J.; Ascoli, G.A. Quantitative firing pattern phenotyping of hippocampal neuron types. Sci. Rep. 2019, 9, 17915. [CrossRef]

42. Rudy, B.; Fishell, G.; Lee, S.; Leffler, J.H. Three groups of interneurons account for nearly $100 \%$ of neocortical GABAergic neurons. Dev. Neurobiol. 2010, 71, 45-61. [CrossRef]

43. Lee, S.; Leffler, J.H.; Zagha, E.; Fishell, G.; Rudy, B. The Largest Group of Superficial Neocortical GABAergic Interneurons Expresses Ionotropic Serotonin Receptors. J. Neurosci. 2010, 30, 16796-16808. [CrossRef]

44. Wamsley, B.; Fishell, B.W.G. Genetic and activity-dependent mechanisms underlying interneuron diversity. Nat. Rev. Neurosci. 2017, 18, 299-309. [CrossRef] [PubMed]

45. Tasic, B.; Menon, V.; Nguyen, T.N.; Kim, T.K.; Jarsky, T.; Yao, Z.; Levi, B.P.; Graybuck, L.; Sorensen, S.A.; Dolbeare, T.A.; et al. Adult mouse cortical cell taxonomy revealed by single cell transcriptomics. Nat. Neurosci. 2016, 19, 335-346. [CrossRef] [PubMed]

46. Tasic, B.; Yao, Z.; Graybuck, L.T.; Smith, K.A.; Nguyen, T.N.; Bertagnolli, D.; Goldy, J.; Garren, E.; Economo, M.N.; Viswanathan, S.; et al. Shared and distinct transcriptomic cell types across neocortical areas. Nature 2018, 563, 72-78. [CrossRef] [PubMed]

47. Zeisel, A.; Muñoz-Manchado, A.B.; Codeluppi, S.; Lönnerberg, P.; La Manno, G.; Juréus, A.; Marques, S.; Munguba, H.; He, L.; Betsholtz, C.; et al. Cell types in the mouse cortex and hippocampus revealed by single-cell RNA-seq. Science 2015, 347, 1138-1142. [CrossRef]

48. Yao, Z.; van Velthoven, C.T.; Nguyen, T.N.; Goldy, J.; Sedeno-Cortes, A.E.; Baftizadeh, F.; Bertagnolli, D.; Casper, T.; Chiang, M.; Crichton, K.; et al. A taxonomy of transcriptomic cell types across the isocortex and hippocampal formation. Cell 2021, 184, 3222-3241.e26. [CrossRef]

49. Yuste, R.; Hawrylycz, M.; Aalling, N.; Aguilar-Valles, A.; Arendt, D.; Armañanzas, R.; Ascoli, G.A.; Bielza, C.; Bokharaie, V.; Bergmann, T.B.; et al. A community-based transcriptomics classification and nomenclature of neocortical cell types. Nat. Neurosci. 2020, 23, 1456-1468. [CrossRef]

50. Armand, E.J.; Li, J.; Xie, F.; Luo, C.; Mukamel, E.A. Single-Cell Sequencing of Brain Cell Transcriptomes and Epigenomes. Neuron 2021, 109, 11-26. [CrossRef]

51. Fuzik, J.; Zeisel, A.; Máté, Z.; Calvigioni, D.; Yanagawa, Y.; Szabó, G.; Linnarsson, S.; Harkany, T. Integration of electrophysiological recordings with single-cell RNA-seq data identifies neuronal subtypes. Nat. Biotechnol. 2015, 34, 175-183. [CrossRef]

52. Gouwens, N.W.; Sorensen, S.A.; Baftizadeh, F.; Budzillo, A.; Lee, B.R.; Jarsky, T.; Alfiler, L.; Baker, K.; Barkan, E.; Berry, K.; et al. Integrated Morphoelectric and Transcriptomic Classification of Cortical GABAergic Cells. Cell 2020, 183, 935-953.e19. [CrossRef] 
53. Fazzari, P.; Mortimer, N.; Yabut, O.; Vogt, D.; Pla, R. Cortical distribution of GABAergic interneurons is determined by migration time and brain size. Development 2020, 147, dev185033. [CrossRef]

54. Ouellet, L.; De Villers-Sidani, E. Trajectory of the main GABAergic interneuron populations from early development to old age in the rat primary auditory cortex. Front. Neuroanat. 2014, 8, 40. [CrossRef]

55. Almási, Z.; Dávid, C.; Witte, M.; Staiger, J.F. Distribution Patterns of Three Molecularly Defined Classes of GABAergic Neurons Across Columnar Compartments in Mouse Barrel Cortex. Front. Neuroanat. 2019, 13, 45. [CrossRef] [PubMed]

56. Kubota, Y.; Shigematsu, N.; Karube, F.; Sekigawa, A.; Kato, S.; Yamaguchi, N.; Hirai, Y.; Morishima, M.; Kawaguchi, Y. Selective Coexpression of Multiple Chemical Markers Defines Discrete Populations of Neocortical GABAergic Neurons. Cereb. Cortex 2011, 21, 1803-1817. [CrossRef] [PubMed]

57. Gonchar, Y.; Wang, Q.; Burkhalter, A.H. Multiple distinct subtypes of GABAergic neurons in mouse visual cortex identified by triple immunostaining. Front. Neuroanat. 2008, 1, 3. [CrossRef] [PubMed]

58. Abs, E.; Poorthuis, R.B.; Apelblat, D.; Muhammad, K.; Pardi, M.B.; Enke, L.; Kushinsky, D.; Pu, D.-L.; Eizinger, M.F.; Conzelmann, K.-K.; et al. Learning-Related Plasticity in Dendrite-Targeting Layer 1 Interneurons. Neuron 2018, 100, 684-699.e6. [CrossRef]

59. Mi, D.; Li, Z.; Lim, L.; Li, M.; Moissidis, M.; Yang, Y.; Gao, T.; Hu, T.X.; Pratt, T.; Price, D.J.; et al. Early emergence of cortical interneuron diversity in the mouse embryo. Science 2018, 360, 81-85. [CrossRef]

60. Turco, J.L.; Kriegstein, A. Clusters of coupled neuroblasts in embryonic neocortex. Science 1991, 252, 563-566. [CrossRef]

61. Bittman, K.; Owens, D.F.; Kriegstein, A.R.; LoTurco, J.J. Cell Coupling and Uncoupling in the Ventricular Zone of Developing Neocortex. J. Neurosci. 1997, 17, 7037-7044. [CrossRef] [PubMed]

62. Nadarajah, B.; Jones, A.M.; Evans, W.H.; Parnavelas, J.G. Differential Expression of Connexins during Neocortical Development and Neuronal Circuit Formation. J. Neurosci. 1997, 17, 3096-3111. [CrossRef] [PubMed]

63. Elias, L.A.; Kriegstein, A.R. Gap junctions: Multifaceted regulators of embryonic cortical development. Trends Neurosci. 2008, 31, 243-250. [CrossRef] [PubMed]

64. Sutor, B.; Hagerty, T. Involvement of gap junctions in the development of the neocortex. Biochim. Biophys. Acta-Biomembr. 2005, 1719, 59-68. [CrossRef]

65. Weissman, T.; Riquelme, P.A.; Ivic, L.; Flint, A.; Kriegstein, A.R. Calcium Waves Propagate through Radial Glial Cells and Modulate Proliferation in the Developing Neocortex. Neuron 2004, 43, 647-661. [CrossRef]

66. Swayne, L.A.; Bennett, S.A.L. Connexins and pannexins in neuronal development and adult neurogenesis. BMC Cell Biol. 2016, 17, S10. [CrossRef]

67. Song, H.; Stevens, C.F.; Gage, F.H. Astroglia induce neurogenesis from adult neural stem cells. Nature 2002, 417, 39-44. [CrossRef]

68. Gelman, D.M.; Griveau, A.; Dehorter, N.; Teissier, A.; Varela, C.; Pla, R.; Pierani, A.; Marín, O. A Wide Diversity of Cortical GABAergic Interneurons Derives from the Embryonic Preoptic Area. J. Neurosci. 2011, 31, 16570-16580. [CrossRef]

69. Bandler, R.C.; Mayer, C.; Fishell, G. Cortical interneuron specification: The juncture of genes, time and geometry. Curr. Opin. Neurobiol. 2016, 42, 17-24. [CrossRef]

70. Petros, T.J.; Bultje, R.S.; Ross, M.E.; Fishell, G.; Anderson, S.A. Apical versus Basal Neurogenesis Directs Cortical Interneuron Subclass Fate. Cell Rep. 2015, 13, 1090-1095. [CrossRef]

71. Hu, J.S.; Vogt, D.; Sandberg, M.; Rubenstein, J.L. Cortical interneuron development: A tale of time and space. Development 2017, 144, 3867-3878. [CrossRef] [PubMed]

72. Montiel, J.F.; Eaboitiz, F. Pallial patterning and the origin of the isocortex. Front. Neurosci. 2015, 9, 377. [CrossRef]

73. Shimogori, T.; Banuchi, V.; Ng, H.Y.; Strauss, J.; Grove, E.A. Embryonic signaling centers expressing BMP, WNT and FGF proteins interact to pattern the cerebral cortex. Development 2004, 131, 5639-5647. [CrossRef]

74. Briscoe, J.; Small, S. Morphogen rules: Design principles of gradient-mediated embryo patterning. Development 2015, 142, 3996-4009. [CrossRef] [PubMed]

75. McKenzie, M.G.; Cobbs, L.V.; Dummer, P.D.; Petros, T.J.; Halford, M.M.; Stacker, S.A.; Zou, Y.; Fishell, G.J.; Au, E. Non-canonical Wnt Signaling through Ryk Regulates the Generation of Somatostatin- and Parvalbumin-Expressing Cortical Interneurons. Neuron 2019, 103, 853-864.e4. [CrossRef] [PubMed]

76. $\mathrm{Xu}, \mathrm{Q}$;; Wonders, C.P.; Anderson, S.A. Sonic hedgehog maintains the identity of cortical interneuron progenitors in the ventral telencephalon. Development 2005, 132, 4987-4998. [CrossRef]

77. Xu, Q.; Guo, L.; Moore, H.; Waclaw, R.R.; Campbell, K.; Anderson, S.A. Sonic Hedgehog Signaling Confers Ventral Telencephalic Progenitors with Distinct Cortical Interneuron Fates. Neuron 2010, 65, 328-340. [CrossRef]

78. Tyson, J.A.; Goldberg, E.; Maroof, A.M.; Xu, Q.; Petros, T.; Anderson, S.A. Duration of culture and sonic hedgehog signaling differentially specify PV versus SST cortical interneuron fates from embryonic stem cells. Development 2015, 142, 1267-1278. [CrossRef]

79. Shimamura, K.; Rubenstein, J. Inductive interactions direct early regionalization of the mouse forebrain. Development 1997, 124, 2709-2718. [CrossRef]

80. Srinivasan, S.; Hu, J.S.; Currle, D.S.; Fung, E.S.; Hayes, W.B.; Lander, A.D.; Monuki, E.S. A BMP-FGF Morphogen Toggle Switch Drives the Ultrasensitive Expression of Multiple Genes in the Developing Forebrain. PLoS Comput. Biol. 2014, 10, e1003463. [CrossRef]

81. Kohtz, J.; Baker, D.; Corte, G.; Fishell, G. Regionalization within the mammalian telencephalon is mediated by changes in responsiveness to Sonic Hedgehog. Development 1998, 125, 5079-5089. [CrossRef] 
82. Anderson, S.A.; Eisenstat, D.D.; Shi, L.; Rubenstein, J.L.R. Interneuron Migration from Basal Forebrain to Neocortex: Dependence on Dlx Genes. Science 1997, 278, 474-476. [CrossRef]

83. Casarosa, S.; Fode, C.; Guillemot, F. Mash1 regulates neurogenesis in the ventral telencephalon. Development 1999, 126, 525-534. [CrossRef]

84. Horton, S.; Meredith, A.; Richardson, J.A.; Johnson, J.E. Correct Coordination of Neuronal Differentiation Events in Ventral Forebrain Requires the bHLH Factor MASH1. Mol. Cell. Neurosci. 1999, 14, 355-369. [CrossRef] [PubMed]

85. He, W.; Ingraham, C.; Rising, L.; Goderie, S.; Temple, S. Multipotent Stem Cells from the Mouse Basal Forebrain Contribute GABAergic Neurons and Oligodendrocytes to the Cerebral Cortex during Embryogenesis. J. Neurosci. 2001, 21, 8854-8862. [CrossRef]

86. Eisenstat, D.D.; Liu, J.K.; Mione, M.; Zhong, W.; Yu, G.; Anderson, S.A.; Ghattas, I.; Puelles, L.; Rubenstein, J.L. DLX-1, DLX-2, and DLX-5 expression define distinct stages of basal forebrain differentiation. J. Comp. Neurol. 1999, 414, 217-237. [CrossRef]

87. Miyoshi, G.; Butt, S.J.B.; Takebayashi, H.; Fishell, G. Physiologically Distinct Temporal Cohorts of Cortical Interneurons Arise from Telencephalic Olig2-Expressing Precursors. J. Neurosci. 2007, 27, 7786-7798. [CrossRef] [PubMed]

88. Sousa, V.; Miyoshi, G.; Leffler, J.H.; Karayannis, T.; Fishell, G. Characterization of Nkx6-2-Derived Neocortical Interneuron Lineages. Cereb. Cortex 2009, 19 (Suppl. 1), i1-i10. [CrossRef]

89. Fogarty, M.; Grist, M.; Gelman, D.; Marin, O.; Pachnis, V.; Kessaris, N. Spatial Genetic Patterning of the Embryonic Neuroepithelium Generates GABAergic Interneuron Diversity in the Adult Cortex. J. Neurosci. 2007, 27, 10935-10946. [CrossRef] [PubMed]

90. Sussel, L.; Marin, O.; Kimura, S.; Rubenstein, J. Loss of Nkx2.1 homeobox gene function results in a ventral to dorsal molecular respecification within the basal telencephalon: Evidence for a transformation of the pallidum into the striatum. Development 1999, 126, 3359-3370. [CrossRef]

91. Du, T.; Xu, Q.; Ocbina, P.J.; Anderson, S.A. NKX2.1 specifies cortical interneuron fate by activating Lhx6. Development 2008, 135, 1559-1567. [CrossRef] [PubMed]

92. Butt, S.; Sousa, V.; Fuccillo, M.; Leffler, J.H.; Miyoshi, G.; Kimura, S.; Fishell, G. The Requirement of Nkx2-1 in the Temporal Specification of Cortical Interneuron Subtypes. Neuron 2008, 59, 722-732. [CrossRef]

93. Flandin, P.; Kimura, S.; Rubenstein, J.L.R. The Progenitor Zone of the Ventral Medial Ganglionic Eminence Requires Nkx2-1 to Generate Most of the Globus Pallidus But Few Neocortical Interneurons. J. Neurosci. 2010, 30, 2812-2823. [CrossRef] [PubMed]

94. Sandberg, M.; Flandin, P.; Silberberg, S.; Su, L.; Price, J.D.; Hu, J.S.; Kim, C.; Visel, A.; Nord, A.S.; Rubenstein, J.L. Transcriptional Networks Controlled by NKX2-1 in the Development of Forebrain GABAergic Neurons. Neuron 2016, 91, 1260-1275. [CrossRef] [PubMed]

95. Flandin, P.; Zhao, Y.; Vogt, D.; Jeong, J.; Long, J.; Potter, G.; Westphal, H.; Rubenstein, J.L. Lhx6 and Lhx8 Coordinately Induce Neuronal Expression of Shh that Controls the Generation of Interneuron Progenitors. Neuron 2011, 70, 939-950. [CrossRef] [PubMed]

96. Alifragis, P.; Liapi, A.; Parnavelas, J.G. Lhx6 Regulates the Migration of Cortical Interneurons from the Ventral Telencephalon But Does Not Specify their GABA Phenotype. J. Neurosci. 2004, 24, 5643-5648. [CrossRef]

97. Neves, G.; Shah, M.M.; Liodis, P.; Achimastou, A.; Denaxa, M.; Roalfe, G.; Sesay, A.; Walker, M.C.; Pachnis, V. The LIM Homeodomain Protein Lhx6 Regulates Maturation of Interneurons and Network Excitability in the Mammalian Cortex. Cereb. Cortex 2012, 23, 1811-1823. [CrossRef]

98. Vogt, D.; Hunt, R.; Mandal, S.; Sandberg, M.; Silberberg, S.N.; Nagasawa, T.; Yang, Z.; Baraban, S.; Rubenstein, J.L. Lhx6 Directly Regulates Arx and CXCR7 to Determine Cortical Interneuron Fate and Laminar Position. Neuron 2014, 82, 350-364. [CrossRef]

99. Liu, Z.; Zhang, Z.; Lindtner, S.; Li, Z.; Xu, Z.; Wei, S.; Liang, Q.; Wen, Y.; Tao, G.; You, Y.; et al. Sp9 Regulates Medial Ganglionic Eminence-Derived Cortical Interneuron Development. Cereb. Cortex 2018, 29, 2653-2667. [CrossRef]

100. Hoch, R.; Lindtner, S.; Price, J.D.; Rubenstein, J.L. OTX2 Transcription Factor Controls Regional Patterning within the Medial Ganglionic Eminence and Regional Identity of the Septum. Cell Rep. 2015, 12, 482-494. [CrossRef]

101. Hu, J.S.; Vogt, D.; Lindtner, S.; Sandberg, M.; Silberberg, S.N.; Rubenstein, J.L.R. Coup-TF1\&2 (Nr2f1 and Nr2f2) control subtype and laminar identity of MGE-derived neocortical interneurons. Development 2017, 144, 2837-2851. [CrossRef] [PubMed]

102. Lodato, S.; Tomassy, G.S.; De Leonibus, E.; Uzcategui, Y.G.; Andolfi, G.; Armentano, M.; Touzot, A.; Gaztelu, J.M.; Arlotta, P.; de la Prida, L.M.; et al. Loss of COUP-TFI Alters the Balance between Caudal Ganglionic Eminence- and Medial Ganglionic Eminence-Derived Cortical Interneurons and Results in Resistance to Epilepsy. J. Neurosci. 2011, 31, 4650-4662. [CrossRef] [PubMed]

103. Kanatani, S.; Yozu, M.; Tabata, H.; Nakajima, K. COUP-TFII Is Preferentially Expressed in the Caudal Ganglionic Eminence and Is Involved in the Caudal Migratory Stream. J. Neurosci. 2008, 28, 13582-13591. [CrossRef] [PubMed]

104. Carney, R.S.; Mangin, J.-M.; Hayes, L.; Mansfield, K.; Sousa, V.H.; Fishell, G.; Machold, R.P.; Ahn, S.; Gallo, V.; Corbin, J.G. Sonic hedgehog expressing and responding cells generate neuronal diversity in the medial amygdala. Neural Dev. 2010, 5, 14 . [CrossRef] [PubMed]

105. Yu, W.; Wang, Y.; McDonnell, K.; Stephen, D.; Bai, C.B. Patterning of ventral telencephalon requires positive function of Gli transcription factors. Dev. Biol. 2009, 334, 264-275. [CrossRef] [PubMed] 
106. Inan, M.; Welagen, J.; Anderson, S.A. Spatial and Temporal Bias in the Mitotic Origins of Somatostatin- and ParvalbuminExpressing Interneuron Subgroups and the Chandelier Subtype in the Medial Ganglionic Eminence. Cereb. Cortex 2011, 22, 820-827. [CrossRef]

107. Magno, L.; Oliveira, M.G.; Mucha, M.; Rubin, A.N.; Kessaris, N. Multiple embryonic origins of nitric oxide synthase-expressing GABAergic neurons of the neocortex. Front. Neural Circuits 2012, 6, 65. [CrossRef]

108. Mayer, C.; Jaglin, X.H.; Cobbs, L.V.; Bandler, R.C.; Streicher, C.; Cepko, C.L.; Hippenmeyer, S.; Fishell, G. Clonally Related Forebrain Interneurons Disperse Broadly across Both Functional Areas and Structural Boundaries. Neuron 2015, 87, 989-998. [CrossRef]

109. Chen, Y.-J.J.; Friedman, B.A.; Ha, C.; Durinck, S.; Liu, J.; Rubenstein, J.L.; Seshagiri, S.; Modrusan, Z. Single-cell RNA sequencing identifies distinct mouse medial ganglionic eminence cell types. Sci. Rep. 2017, 7, 45656. [CrossRef]

110. Ciceri, G.; Dehorter, N.; Sols, I.; Huang, Z.J.; Maravall, M.; Marín, O. Lineage-specific laminar organization of cortical GABAergic interneurons. Nat. Neurosci. 2013, 16, 1199-1210. [CrossRef]

111. Harwell, C.C.; Fuentealba, L.C.; Gonzalez-Cerrillo, A.; Parker, P.R.L.; Gertz, C.C.; Mazzola, E.; García, M.T.; Alvarez-Buylla, A.; Cepko, C.L.; Kriegstein, A.R. Wide Dispersion and Diversity of Clonally Related Inhibitory Interneurons. Neuron 2015, 87, 999-1007. [CrossRef]

112. Miyoshi, G. Elucidating the developmental trajectories of GABAergic cortical interneuron subtypes. Neurosci. Res. 2018, 138, 26-32. [CrossRef]

113. Malik, R.; Pai, E.L.-L.; Rubin, A.N.; Stafford, A.M.; Angara, K.; Minasi, P.; Rubenstein, J.L.; Sohal, V.S.; Vogt, D. Tsc1 represses parvalbumin expression and fast-spiking properties in somatostatin lineage cortical interneurons. Nat. Commun. 2019, 10, 1-16. [CrossRef]

114. Petros, T.J.; Maurer, C.; Anderson, S.A. Enhanced derivation of mouse ESC-derived cortical interneurons by expression of Nkx2.1. Stem Cell Res. 2013, 11, 647-656. [CrossRef]

115. Nasu, M.; Esumi, S.; Hatakeyama, J.; Tamamaki, N.; Shimamura, K. Two-Phase Lineage Specification of Telencephalon Progenitors Generated From Mouse Embryonic Stem Cells. Front. Cell Dev. Biol. 2021, 9, 632381. [CrossRef]

116. Trevino, A.E.; Müller, F.; Andersen, J.; Sundaram, L.; Kathiria, A.; Shcherbina, A.; Farh, K.; Chang, H.Y.; Pașca, A.M.; Kundaje, A.; et al Chromatin and gene-regulatory dynamics of the developing human cerebral cortex at single-cell resolution. Cell 2021. [CrossRef]

117. Moffitt, J.R.; Bambah-Mukku, D.; Eichhorn, S.W.; Vaughn, E.; Shekhar, K.; Perez, J.D.; Rubinstein, N.D.; Hao, J.; Regev, A.; Dulac, C.; et al. Molecular, spatial, and functional single-cell profiling of the hypothalamic preoptic region. Science 2018, 362, eaau5324. [CrossRef] [PubMed]

118. Di Bella, D.J.; Habibi, E.; Stickels, R.R.; Scalia, G.; Brown, J.; Yadollahpour, P.; Yang, S.M.; Abbate, C.; Biancalani, T.; Macosko, E.Z.; et al. Molecular logic of cellular diversification in the mouse cerebral cortex. Nature 2021, 595, 554-559. [CrossRef] [PubMed]

119. Lim, L.; Mi, D.; Llorca, A.; Marín, O. Development and Functional Diversification of Cortical Interneurons. Neuron 2018, 100, 294-313. [CrossRef] [PubMed]

120. Marsh, E.D.; Nasrallah, M.P.; Walsh, C.; Murray, K.A.; Sunnen, C.N.; McCoy, A.; Golden, J.A. Developmental interneuron subtype deficits after targeted loss of Arx. BMC Neurosci. 2016, 17, 35. [CrossRef]

121. Yang, Y.; Shen, W.; Ni, Y.; Su, Y.; Yang, Z.; Zhao, C. Impaired Interneuron Development afterFoxg1Disruption. Cereb. Cortex 2015, 27, 793-808. [CrossRef] [PubMed]

122. Talebian, A.; Britton, R.; Ammanuel, S.; Bepari, A.; Sprouse, F.; Birnbaum, S.G.; Szabó, G.; Tamamaki, N.; Gibson, J.; Henkemeyer, M. Autonomous and non-autonomous roles for ephrin-B in interneuron migration. Dev. Biol. 2017, 431, 179-193. [CrossRef] [PubMed]

123. Bortone, D.; Polleux, F. KCC2 Expression Promotes the Termination of Cortical Interneuron Migration in a Voltage-Sensitive Calcium-Dependent Manner. Neuron 2009, 62, 53-71. [CrossRef] [PubMed]

124. Inamura, N.; Kimura, T.; Tada, S.; Kurahashi, T.; Yanagida, M.; Yanagawa, Y.; Ikenaka, K.; Murakami, F. Intrinsic and Extrinsic Mechanisms Control the Termination of Cortical Interneuron Migration. J. Neurosci. 2012, 32, 6032-6042. [CrossRef]

125. Behar, T.N.; Li, Y.X.; Tran, H.T.; Ma, W.; Dunlap, V.; Scott, C.; Barker, J.L. GABA stimulates chemotaxis and chemokinesis of embryonic cortical neurons via calcium-dependent mechanisms. J. Neurosci. 1996, 16, 1808-1818. [CrossRef] [PubMed]

126. Luhmann, H.J.; Efukuda, A.; Ekilb, W. Control of cortical neuronal migration by glutamate and GABA. Front. Cell. Neurosci. 2015, 9, 4. [CrossRef]

127. Southwell, D.G.; Paredes, M.F.; Galvao, R.P.; Jones, D.L.; Froemke, R.; Sebe, J.Y.; Alfaro-Cervello, C.; Tang, Y.; García-Verdugo, J.M.; Rubenstein, J.L.; et al. Intrinsically determined cell death of developing cortical interneurons. Nature 2012, 491, 109-113. [CrossRef]

128. Denaxa, M.; Neves, G.; Rabinowitz, A.; Kemlo, S.; Liodis, P.; Burrone, J.; Pachnis, V. Modulation of Apoptosis Controls Inhibitory Interneuron Number in the Cortex. Cell Rep. 2018, 22, 1710-1721. [CrossRef]

129. Priya, R.; Paredes, M.F.; Karayannis, T.; Yusuf, N.; Liu, X.; Jaglin, X.; Graef, I.; Alvarez-Buylla, A.; Fishell, G. Activity Regulates Cell Death within Cortical Interneurons through a Calcineurin-Dependent Mechanism. Cell Rep. 2018, 22, 1695-1709. [CrossRef]

130. Yamaguchi, Y.; Miura, M. Programmed Cell Death in Neurodevelopment. Dev. Cell 2015, 32, 478-490. [CrossRef]

131. Leon, W.R.M.; Spatazza, J.; Rakela, B.; Chatterjee, A.; Pande, V.; Maniatis, T.; Hasenstaub, A.R.; Stryker, M.P.; Alvarez-Buylla, A. Clustered gamma-protocadherins regulate cortical interneuron programmed cell death. ELife 2020, 9, e55374. [CrossRef] [PubMed] 
132. Wong, F.K.; Bercsenyi, K.; Sreenivasan, V.; Portalés, A.; Fernández-Otero, M.; Marín, O. Pyramidal cell regulation of interneuron survival sculpts cortical networks. Nature 2018, 557, 668-673. [CrossRef] [PubMed]

133. Duan, Z.R.S.; Che, A.; Chu, P.; Modol, L.; Bollmann, Y.; Babij, R.; Fetcho, R.N.; Otsuka, T.; Fuccillo, M.V.; Liston, C.; et al. GABAergic Restriction of Network Dynamics Regulates Interneuron Survival in the Developing Cortex. Neuron 2019, 105, 75-92.e5. [CrossRef] [PubMed]

134. Blanquie, O.; Yang, J.-W.; Kilb, W.; Sharopov, S.; Sinning, A.; Luhmann, H.J. Electrical activity controls area-specific expression of neuronal apoptosis in the mouse developing cerebral cortex. ELife 2017, 6, e27696. [CrossRef]

135. Castillo-Ruiz, A.; Hite, T.; Yakout, D.W.; Rosen, T.J.; Forger, N.G. Does Birth Trigger Cell Death in the Developing Brain? Eneuro 2020, 7, 1-11. [CrossRef]

136. Himmelhan, D.; Rawashdeh, O.; Oelschläger, H. Early postnatal development of the visual cortex in mice with retinal degeneration. Mech. Dev. 2018, 151, 1-9. [CrossRef]

137. Forloni, G.; Hohmann, C.; Coyle, J.T. Developmental expression of somatostatin in mouse brain. I. Immunocytochemical studies. Dev. Brain Res. 1990, 53, 6-25. [CrossRef]

138. Hogan, D.; Berman, N.E. The development of somatostatin immunoreactive neurons in cat visual cortical areas. Dev. Brain Res. 1993, 71, 221-238. [CrossRef]

139. Liguz-Lecznar, M.; Urban-Ciecko, J.; Kossut, M. Somatostatin and Somatostatin-Containing Neurons in Shaping Neuronal Activity and Plasticity. Front. Neural Circuits 2016, 10, 48. [CrossRef]

140. Bitzenhofer, S.H.; Pöpplau, J.A.; Hanganu-Opatz, I. Gamma activity accelerates during prefrontal development. ELife 2020, 9, e56795. [CrossRef]

141. Pan, G.; Yang, J.-M.; Hu, X.-Y.; Li, X.-M. Postnatal development of the electrophysiological properties of somatostatin interneurons in the anterior cingulate cortex of mice. Sci. Rep. 2016, 6, 28137. [CrossRef]

142. Pan, N.C.; Fang, A.; Shen, C.; Sun, L.; Wu, Q.; Wang, X. Early Excitatory Activity-Dependent Maturation of Somatostatin Interneurons in Cortical Layer 2/3 of Mice. Cereb. Cortex 2018, 29, 4107-4118. [CrossRef]

143. Kinnischtzke, A.K.; Sewall, A.M.; Berkepile, J.M.; Fanselow, E.E. Postnatal maturation of somatostatin-expressing inhibitory cells in the somatosensory cortex of GIN mice. Front. Neural Circuits 2012, 6, 33. [CrossRef] [PubMed]

144. Yang, J.-M.; Zhang, J.; Yu, Y.-Q.; Duan, S.; Li, X.-M. Postnatal Development of 2 Microcircuits Involving Fast-Spiking Interneurons in the Mouse Prefrontal Cortex. Cereb. Cortex 2012, 24, 98-109. [CrossRef] [PubMed]

145. Miyamae, T.; Chen, K.; Lewis, D.A.; Gonzalez-Burgos, G. Distinct Physiological Maturation of Parvalbumin-Positive Neuron Subtypes in Mouse Prefrontal Cortex. J. Neurosci. 2017, 37, 4883-4902. [CrossRef] [PubMed]

146. Okaty, B.W.; Miller, M.N.; Sugino, K.; Hempel, C.M.; Nelson, S.B. Transcriptional and Electrophysiological Maturation of Neocortical Fast-Spiking GABAergic Interneurons. J. Neurosci. 2009, 29, 7040-7052. [CrossRef]

147. Pangratz-Fuehrer, S.; Hestrin, S. Synaptogenesis of Electrical and GABAergic Synapses of Fast-Spiking Inhibitory Neurons in the Neocortex. J. Neurosci. 2011, 31, 10767-10775. [CrossRef]

148. Lazarus, M.S.; Huang, Z.J. Distinct maturation profiles of perisomatic and dendritic targeting GABAergic interneurons in the mouse primary visual cortex during the critical period of ocular dominance plasticity. J. Neurophysiol. 2011, 106, 775-787. [CrossRef]

149. Lu, J.; Tucciarone, J.; Lin, Y.; Huang, Z.J. Input-specific maturation of synaptic dynamics of parvalbumin interneurons in primary visual cortex. Proc. Natl. Acad. Sci. USA 2014, 111, 16895-16900. [CrossRef] [PubMed]

150. Zhang, X.-J.; Li, Z.; Han, Z.; Sultan, K.T.; Huang, K.; Shi, S.-H. Precise inhibitory microcircuit assembly of developmentally related neocortical interneurons in clusters. Nat. Commun. 2017, 8, 16091. [CrossRef]

151. Guan, W.; Cao, J.-W.; Liu, L.-Y.; Zhao, Z.-H.; Fu, Y.; Yu, Y.-C. Eye opening differentially modulates inhibitory synaptic transmission in the developing visual cortex. ELife 2017, 6, e32337. [CrossRef] [PubMed]

152. Reh, R.K.; Dias, B.G.; Nelson, C.A.; Kaufer, D.; Werker, J.F.; Kolb, B.; Levine, J.D.; Hensch, T.K. Critical period regulation across multiple timescales. Proc. Natl. Acad. Sci. USA 2020, 117, 23242-23251. [CrossRef]

153. Donato, F.; Rompani, S.; Caroni, P. Parvalbumin-expressing basket-cell network plasticity induced by experience regulates adult learning. Nature 2013, 504, 272-276. [CrossRef]

154. Lussier, S.J.; Stevens, H.E. Delays in GABAergic interneuron development and behavioral inhibition after prenatal stress. Dev. Neurobiol. 2016, 76, 1078-1091. [CrossRef] [PubMed]

155. Tuncdemir, S.; Wamsley, B.; Stam, F.J.; Osakada, F.; Goulding, M.; Callaway, E.; Rudy, B.; Fishell, G. Early Somatostatin Interneuron Connectivity Mediates the Maturation of Deep Layer Cortical Circuits. Neuron 2016, 89, 521-535. [CrossRef] [PubMed]

156. Modol, L.; Sousa, V.H.; Malvache, A.; Tressard, T.; Baude, A.; Cossart, R. Spatial Embryonic Origin Delineates GABAergic Hub Neurons Driving Network Dynamics in the Developing Entorhinal Cortex. Cereb. Cortex 2017, 27, 4649-4661. [CrossRef] [PubMed]

157. Wang, C.-Z.; Ma, J.; Xu, Y.-Q.; Jiang, S.-N.; Chen, T.-Q.; Yuan, Z.-L.; Mao, X.-Y.; Zhang, S.-Q.; Liu, L.-Y.; Fu, Y.; et al. Early-generated interneurons regulate neuronal circuit formation during early postnatal development. ELife 2019, 8, e44649. [CrossRef]

158. Su, J.; Chen, J.; Lippold, K.; Monavarfeshani, A.; Carrillo, G.L.; Jenkins, R.; Fox, M.A. Collagen-derived matricryptins promote inhibitory nerve terminal formation in the developing neocortex. J. Cell Biol. 2016, 212, 721-736. [CrossRef]

159. Su, J.; Gorse, K.; Ramirez, F.; Fox, M.A. Collagen XIX is expressed by interneurons and contributes to the formation of hippocampal synapses. J. Comp. Neurol. 2009, 518, 229-253. [CrossRef] 
160. Su, J.; Basso, D.; Iyer, S.; Su, K.; Wei, J.; Fox, M.A. Paracrine Role for Somatostatin Interneurons in the Assembly of Perisomatic Inhibitory Synapses. J. Neurosci. 2020, 40, 7421-7435. [CrossRef]

161. Keck, T.; Scheuss, V.; Jacobsen, R.I.; Wierenga, C.J.; Eysel, U.T.; Bonhoeffer, T.; Hübener, M. Loss of Sensory Input Causes Rapid Structural Changes of Inhibitory Neurons in Adult Mouse Visual Cortex. Neuron 2011, 71, 869-882. [CrossRef]

162. Scheuss, V.; Bonhoeffer, T. Function of Dendritic Spines on Hippocampal Inhibitory Neurons. Cereb. Cortex 2013, 24, 3142-3153. [CrossRef]

163. Oray, S.; Majewska, A.; Sur, I. Effects of Synaptic Activity on Dendritic Spine Motility of Developing Cortical Layer V Pyramidal Neurons. Cereb. Cortex 2005, 16, 730-741. [CrossRef]

164. Oh, W.C.; Lutzu, S.; Castillo, P.E.; Kwon, H.-B. De novo synaptogenesis induced by GABA in the developing mouse cortex. Science 2016, 353, 1037-1040. [CrossRef]

165. Gómez-Climent, M.; Guirado, R.; Castillo-Gómez, E.; Varea, E.; Gutierrez-Mecinas, M.; Gilabert-Juan, J.; Mompo, C.G.; Vidueira, S.; Sanchez-Mataredona, D.; Hernández-González, S.; et al. The Polysialylated Form of the Neural Cell Adhesion Molecule (PSANCAM) Is Expressed in a Subpopulation of Mature Cortical Interneurons Characterized by Reduced Structural Features and Connectivity. Cereb. Cortex 2010, 21, 1028-1041. [CrossRef] [PubMed]

166. Guirado, R.; Perez-Rando, M.; Sanchez-Matarredona, D.; Castillo-Gómez, E.; Liberia, T.; Rovira-Esteban, L.; Varea, E.; Crespo, C.; Blasco-Ibáñez, J.M.; Nacher, J. The Dendritic Spines of Interneurons Are Dynamic Structures Influenced by PSA-NCAM Expression. Cereb. Cortex 2013, 24, 3014-3024. [CrossRef] [PubMed]

167. Chen, S.X.; Na Kim, A.; Peters, A.J.; Komiyama, T. Subtype-specific plasticity of inhibitory circuits in motor cortex during motor learning. Nat. Neurosci. 2015, 18, 1109-1115. [CrossRef]

168. Hestrin, S.; Galarreta, M. Electrical synapses define networks of neocortical GABAergic neurons. Trends Neurosci. 2005, 28, 304-309. [CrossRef] [PubMed]

169. Druga, R. Neocortical inhibitory system. Folia Biol. 2009, 55, 201-217.

170. Blümcke, I.; Hof, P.R.; Morrison, J.H.; Celio, M.R. Distribution of parvalbumin immunoreactivity in the visual cortex of Old World monkeys and humans. J. Comp. Neurol. 1990, 301, 417-432. [CrossRef] [PubMed]

171. Freund, T.F.; Buzsaki, G. Interneurons of the hippocampus. Hippocampus 1996, 6, 347-470. [CrossRef] [PubMed]

172. Kawaguchi, Y.; Karube, F.; Kubota, Y. Dendritic Branch Typing and Spine Expression Patterns in Cortical Nonpyramidal Cells. Cereb. Cortex 2005, 16, 696-711. [CrossRef]

173. Sancho, L.; Bloodgood, B.L. Functional Distinctions between Spine and Dendritic Synapses Made onto Parvalbumin-Positive Interneurons in Mouse Cortex. Cell Rep. 2018, 24, 2075-2087. [CrossRef]

174. Soriano, E.; Nitsch, R.; Frotscher, M. Axo-axonic chandelier cells in the rat fascia dentata: Golgi-electron microscopy and immunocytochemical studies. J. Comp. Neurol. 1990, 293, 1-25. [CrossRef] [PubMed]

175. Taniguchi, H.; Lu, J.; Huang, Z.J. The Spatial and Temporal Origin of Chandelier Cells in Mouse Neocortex. Science 2012, 339, 70-74. [CrossRef] [PubMed]

176. Fish, K.; Hoftman, G.D.; Sheikh, W.; Kitchens, M.; Lewis, D.A. Parvalbumin-Containing Chandelier and Basket Cell Boutons Have Distinctive Modes of Maturation in Monkey Prefrontal Cortex. J. Neurosci. 2013, 33, 8352-8358. [CrossRef] [PubMed]

177. Cauli, B.; Audinat, E.; Lambolez, B.; Angulo, M.C.; Ropert, N.; Tsuzuki, K.; Hestrin, S.; Rossier, J. Molecular and Physiological Diversity of Cortical Nonpyramidal Cells. J. Neurosci. 1997, 17, 3894-3906. [CrossRef]

178. Pohlkamp, T.; Dávid, C.; Cauli, B.; Gallopin, T.; Bouché, E.; Karagiannis, A.; May, P.; Herz, J.; Frotscher, M.; Staiger, J.F.; et al. Characterization and Distribution of Reelin-Positive Interneuron Subtypes in the Rat Barrel Cortex. Cereb. Cortex 2013, 24, 3046-3058. [CrossRef]

179. Tai, Y.; Gallo, N.B.; Wang, M.; Yu, J.-R.; Van Aelst, L. Axo-axonic Innervation of Neocortical Pyramidal Neurons by GABAergic Chandelier Cells Requires AnkyrinG-Associated L1CAM. Neuron 2019, 102, 358-372.e9. [CrossRef]

180. Tai, Y.; Janas, J.A.; Wang, C.-L.; Van Aelst, L. Regulation of Chandelier Cell Cartridge and Bouton Development via DOCK7Mediated ErbB4 Activation. Cell Rep. 2014, 6, 254-263. [CrossRef]

181. Ishino, Y.; Yetman, M.J.; Sossi, S.M.; Steinecke, A.; Hayano, Y.; Taniguchi, H. Regional Cellular Environment Shapes Phenotypic Variations of Hippocampal and Neocortical Chandelier Cells. J. Neurosci. 2017, 37, 9901-9916. [CrossRef]

182. Daigle, T.L.; Madisen, L.; Hage, T.A.; Valley, M.T.; Knoblich, U.; Larsen, R.S.; Takeno, M.M.; Huang, L.; Gu, H.; Larsen, R.; et al. A Suite of Transgenic Driver and Reporter Mouse Lines with Enhanced Brain-Cell-Type Targeting and Functionality. Cell 2018, 174, 465-480.e22. [CrossRef]

183. Lee, A.T.; Vogt, D.; Rubenstein, J.L.; Sohal, V.S. A Class of GABAergic Neurons in the Prefrontal Cortex Sends Long-Range Projections to the Nucleus Accumbens and Elicits Acute Avoidance Behavior. J. Neurosci. 2014, 34, 11519-11525. [CrossRef] [PubMed]

184. Zurita, H.; Feyen, P.L.C.; Apicella, A.J. Layer 5 Callosal Parvalbumin-Expressing Neurons: A Distinct Functional Group of GABAergic Neurons. Front. Cell. Neurosci. 2018, 12, 53. [CrossRef]

185. Bertero, A.; Zurita, H.; Normandin, M.; Apicella, A.J. Auditory Long-Range Parvalbumin Cortico-Striatal Neurons. Front. Neural Circuits 2020, 14, 45. [CrossRef]

186. Wang, L.-Y.; Gan, L.; Forsythe, I.; Kaczmarek, L.K. Contribution of the Kv3.1 potassium channel to high-frequency firing in mouse auditory neurones. J. Physiol. 1998, 509, 183-194. [CrossRef] [PubMed] 
187. Boddum, K.; Hougaard, C.; Lin, J.X.-Y.; von Schoubye, N.L.; Jensen, H.S.; Grunnet, M.; Jespersen, T. Kv3.1/Kv3.2 channel positive modulators enable faster activating kinetics and increase firing frequency in fast-spiking GABAergic interneurons. Neuropharmacology 2017, 118, 102-112. [CrossRef] [PubMed]

188. Ma, Y.; Hu, H.; Berrebi, A.S.; Mathers, P.H.; Agmon, A. Distinct Subtypes of Somatostatin-Containing Neocortical Interneurons Revealed in Transgenic Mice. J. Neurosci. 2006, 26, 5069-5082. [CrossRef]

189. Buchanan, K.A.; Sjöström, P.J. A piece of the neocortical puzzle: The pyramid-Martinotti cell reciprocating principle. J. Physiol. 2009, 587, 5301-5302. [CrossRef] [PubMed]

190. Marlin, J.J.; Carter, A.G. GABA-A Receptor Inhibition of Local Calcium Signaling in Spines and Dendrites. J. Neurosci. 2014, 34, 15898-15911. [CrossRef] [PubMed]

191. Xu, H.; Jeong, H.-Y.; Tremblay, R.; Rudy, B. Neocortical Somatostatin-Expressing GABAergic Interneurons Disinhibit the Thalamorecipient Layer 4. Neuron 2013, 77, 155-167. [CrossRef] [PubMed]

192. Pfeffer, C.K.; Xue, M.; He, M.; Huang, Z.J.; Scanziani, M. Inhibition of inhibition in visual cortex: The logic of connections between molecularly distinct interneurons. Nat. Neurosci. 2013, 16, 1068-1076. [CrossRef]

193. Sohn, J.; Okamoto, S.; Kataoka, N.; Kaneko, T.; Nakamura, K.; Hioki, H. Differential Inputs to the Perisomatic and Distal-Dendritic Compartments of VIP-Positive Neurons in Layer 2/3 of the Mouse Barrel Cortex. Front. Neuroanat. 2016, 10, 124. [CrossRef] [PubMed]

194. Hioki, H.; Okamoto, S.; Konno, M.; Kameda, H.; Sohn, J.; Kuramoto, E.; Fujiyama, F.; Kaneko, T. Cell Type-Specific Inhibitory Inputs to Dendritic and Somatic Compartments of Parvalbumin-Expressing Neocortical Interneuron. J. Neurosci. 2013, 33, 544-555. [CrossRef]

195. Fanselow, E.E.; Richardson, K.A.; Connors, B.W. Selective, State-Dependent Activation of Somatostatin-Expressing Inhibitory Interneurons in Mouse Neocortex. J. Neurophysiol. 2008, 100, 2640-2652. [CrossRef]

196. Beierlein, M.; Gibson, J.R.; Connors, B. A network of electrically coupled interneurons drives synchronized inhibition in neocortex. Nat. Neurosci. 2000, 3, 904-910. [CrossRef] [PubMed]

197. Sohn, J.; Hioki, H.; Okamoto, S.; Kaneko, T. Preprodynorphin-expressing neurons constitute a large subgroup of somatostatinexpressing GABAergic interneurons in the mouse neocortex. J. Comp. Neurol. 2014, 522, 1506-1526. [CrossRef] [PubMed]

198. Markram, H.; Muller, E.; Ramaswamy, S.; Reimann, M.W.; Abdellah, M.; Sanchez, C.A.; Ailamaki, A.; Alonso-Nanclares, L.; Antille, N.; Arsever, S.; et al. Reconstruction and Simulation of Neocortical Microcircuitry. Cell 2015, 163, 456-492. [CrossRef]

199. Tamamaki, N.; Tomioka, R. Long-Range GABAergic Connections Distributed throughout the Neocortex and their Possible Function. Front. Behav. Neurosci. 2010, 4, 202. [CrossRef]

200. Tomioka, R.; Okamoto, K.; Furuta, T.; Fujiyama, F.; Iwasato, T.; Yanagawa, Y.; Obata, K.; Kaneko, T.; Tamamaki, N. Demonstration of long-range GABAergic connections distributed throughout the mouse neocortex. Eur. J. Neurosci. 2005, 21, 1587-1600. [CrossRef]

201. Tomioka, R.; Sakimura, K.; Yanagawa, Y. Corticofugal GABAergic projection neurons in the mouse frontal cortex. Front. Neuroanat. 2015, 9, 133. [CrossRef]

202. Demars, M.P.; Morishita, H. Cortical parvalbumin and somatostatin GABA neurons express distinct endogenous modulators of nicotinic acetylcholine receptors. Mol. Brain 2014, 7, 75. [CrossRef]

203. Bertero, A.; Feyen, P.L.C.; Zurita, H.; Apicella, A.J. A Non-Canonical Cortico-Amygdala Inhibitory Loop. J. Neurosci. 2019, 39 , 8424-8438. [CrossRef]

204. Wall, N.R.; De La Parra, M.; Sorokin, J.M.; Taniguchi, H.; Huang, Z.J.; Callaway, E.M. Brain-Wide Maps of Synaptic Input to Cortical Interneurons. J. Neurosci. 2016, 36, 4000-4009. [CrossRef]

205. Jouhanneau, J.-S.; Kremkow, J.; Poulet, J.F.A. Single synaptic inputs drive high-precision action potentials in parvalbumin expressing GABA-ergic cortical neurons in vivo. Nat. Commun. 2018, 9, 1-11. [CrossRef]

206. Ferrer, C.; Hsieh, H.; Wollmuth, L.P. Input-specific maturation of NMDAR-mediated transmission onto parvalbumin-expressing interneurons in layers 2/3 of the visual cortex. J. Neurophysiol. 2018, 120, 3063-3076. [CrossRef]

207. Dudok, B.; Klein, P.M.; Hwaun, E.; Lee, B.R.; Yao, Z.; Fong, O.; Bowler, J.C.; Terada, S.; Sparks, F.T.; Szabo, G.G.; et al. Alternating sources of perisomatic inhibition during behavior. Neuron 2021, 109, 997-1012.e9. [CrossRef]

208. Valero, M.; Viney, T.J.; Machold, R.; Mederos, S.; Zutshi, I.; Schuman, B.; Senzai, Y.; Rudy, B.; Buzsáki, G. Sleep down state-active ID2/Nkx2.1 interneurons in the neocortex. Nat. Neurosci. 2021, 24, 401-411. [CrossRef]

209. Pi, H.-J.; Hangya, B.; Kvitsiani, D.; Sanders, J.I.; Huang, Z.J.; Kepecs, A. Cortical interneurons that specialize in disinhibitory control. Nature 2013, 503, 521-524. [CrossRef]

210. Jackson, J.; Ayzenshtat, I.; Karnani, M.M.; Yuste, R. VIP+ interneurons control neocortical activity across brain states. J. Neurophysiol. 2016, 115, 3008-3017. [CrossRef]

211. Karnani, M.M.; Jackson, J.; Ayzenshtat, I.; Sichani, A.H.; Manoocheri, K.; Kim, S.; Yuste, R. Opening Holes in the Blanket of Inhibition: Localized Lateral Disinhibition by VIP Interneurons. J. Neurosci. 2016, 36, 3471-3480. [CrossRef]

212. Cummings, K.A.; Clem, R.L. Prefrontal somatostatin interneurons encode fear memory. Nat. Neurosci. 2019, 23, 61-74. [CrossRef]

213. Naskar, S.; Qi, J.; Pereira, F.; Gerfen, C.R.; Lee, S. Cell-type-specific recruitment of GABAergic interneurons in the primary somatosensory cortex by long-range inputs. Cell Rep. 2021, 34, 108774. [CrossRef] 
214. Scheyltjens, I.; Vreysen, S.; Haute, C.V.D.; Sabanov, V.; Balschun, D.; Baekelandt, V.; Arckens, L. Transient and localized optogenetic activation of somatostatin-interneurons in mouse visual cortex abolishes long-term cortical plasticity due to vision loss. Brain Struct. Funct. 2018, 223, 2073-2095. [CrossRef]

215. Ma, Y.; Hu, H.; Agmon, A. Short-Term Plasticity of Unitary Inhibitory-to-Inhibitory Synapses Depends on the Presynaptic Interneuron Subtype. J. Neurosci. 2012, 32, 983-988. [CrossRef]

216. Kapfer, C.; Glickfeld, L.L.; Atallah, B.; Scanziani, M. Supralinear increase of recurrent inhibition during sparse activity in the somatosensory cortex. Nat. Neurosci. 2007, 10, 743-753. [CrossRef]

217. Pala, A.; Petersen, C.C. State-dependent cell-type-specific membrane potential dynamics and unitary synaptic inputs in awake mice. ELife 2018, 7, e35869. [CrossRef]

218. Hioki, H.; Sohn, J.; Nakamura, H.; Okamoto, S.; Hwang, J.; Ishida, Y.; Takahashi, M.; Kameda, H. Preferential inputs from cholecystokinin-positive neurons to the somatic compartment of parvalbumin-expressing neurons in the mouse primary somatosensory cortex. Brain Res. 2018, 1695, 18-30. [CrossRef]

219. Galarreta, M.; Hestrin, S. Electrical and chemical synapses among parvalbumin fast-spiking GABAergic interneurons in adult mouse neocortex. Proc. Natl. Acad. Sci. USA 2002, 99, 12438-12443. [CrossRef]

220. Amitai, Y.; Gibson, J.R.; Beierlein, M.; Patrick, S.L.; Ho, A.M.; Connors, B.; Golomb, D. The Spatial Dimensions of Electrically Coupled Networks of Interneurons in the Neocortex. J. Neurosci. 2002, 22, 4142-4152. [CrossRef]

221. Shigematsu, N.; Nishi, A.; Fukuda, T. Gap Junctions Interconnect Different Subtypes of Parvalbumin-Positive Interneurons in Barrels and Septa with Connectivity Unique to Each Subtype. Cereb. Cortex 2018, 29, 1414-1429. [CrossRef]

222. Woodruff, A.R.; McGarry, L.M.; Vogels, T.P.; Inan, M.; Anderson, S.A.; Yuste, R. State-Dependent Function of Neocortical Chandelier Cells. J. Neurosci. 2011, 31, 17872-17886. [CrossRef]

223. Tikhonova, T.B.; Miyamae, T.; Gulchina, Y.; Lewis, D.A.; Gonzalez-Burgos, G. Cell Type- and Layer-Specific Muscarinic Potentiation of Excitatory Synaptic Drive onto Parvalbumin Neurons in Mouse Prefrontal Cortex. Eneuro 2018, 5, 1-21. [CrossRef]

224. Aracri, P.; Meneghini, S.; Coatti, A.; Amadeo, A.; Becchetti, A. $\alpha 4 \beta 2 *$ nicotinic receptors stimulate GABA release onto fast-spiking cells in layer V of mouse prefrontal (Fr2) cortex. Neuroscience 2016, 340, 48-61. [CrossRef]

225. Jones, A.F.; Sheets, P.L. Sex-Specific Disruption of Distinct mPFC Inhibitory Neurons in Spared-Nerve Injury Model of Neuropathic Pain. Cell Rep. 2020, 31, 107729. [CrossRef] [PubMed]

226. Jin, X.; Jiang, K.; Prince, D.A. Excitatory and inhibitory synaptic connectivity to layer V fast-spiking interneurons in the freeze lesion model of cortical microgyria. J. Neurophysiol. 2014, 112, 1703-1713. [CrossRef] [PubMed]

227. Fuchs, T.; Jefferson, S.J.; Hooper, A.; Yee, P.-H.; Maguire, J.; Luscher, B. Disinhibition of somatostatin-positive GABAergic interneurons results in an anxiolytic and antidepressant-like brain state. Mol. Psychiatry 2016, 22, 920-930. [CrossRef] [PubMed]

228. Koppensteiner, P.; Von Itter, R.; Melani, R.; Galvin, C.; Lee, F.S.; Ninan, I. Diminished Fear Extinction in Adolescents Is Associated with an Altered Somatostatin Interneuron-Mediated Inhibition in the Infralimbic Cortex. Biol. Psychiatry 2019, 86, 682-692. [CrossRef]

229. Williams, R.H.; Vazquez-DeRose, J.; Thomas, A.M.; Piquet, J.; Cauli, B.; Kilduff, T.S. Cortical nNOS/NK1 Receptor Neurons are Regulated by Cholinergic Projections from the Basal Forebrain. Cereb. Cortex 2017, 28, 1959-1979. [CrossRef]

230. Kawaguchi, Y. Selective Cholinergic Modulation of Cortical GABAergic Cell Subtypes. J. Neurophysiol. 1997, $78,1743-1747$. [CrossRef]

231. Kuki, T.; Fujihara, K.; Miwa, H.; Tamamaki, N.; Yanagawa, Y.; Mushiake, H. Contribution of parvalbumin and somatostatinexpressing GABAergic neurons to slow oscillations and the balance in beta-gamma oscillations across cortical layers. Front. Neural Circuits 2015, 9, 6. [CrossRef]

232. Grenier, F.; Timofeev, I.; Steriade, M. Focal Synchronization of Ripples (80-200 Hz) in Neocortex and Their Neuronal Correlates. J. Neurophysiol. 2001, 86, 1884-1898. [CrossRef]

233. Vyazovskiy, V.; Olcese, U.; Lazimy, Y.M.; Faraguna, U.; Esser, S.K.; Williams, J.C.; Cirelli, C.; Tononi, G. Cortical Firing and Sleep Homeostasis. Neuron 2009, 63, 865-878. [CrossRef] [PubMed]

234. Niethard, N.; Burgalossi, A.; Born, J. Plasticity during Sleep Is Linked to Specific Regulation of Cortical Circuit Activity. Front. Neural Circuits 2017, 11, 65. [CrossRef] [PubMed]

235. Niethard, N.; Ngo, H.-V.V.; Ehrlich, I.; Born, J. Cortical circuit activity underlying sleep slow oscillations and spindles. Proc. Natl. Acad. Sci. USA 2018, 115, E9220-E9229. [CrossRef]

236. Niethard, N.; Hasegawa, M.; Itokazu, T.; Oyanedel, C.; Born, J.; Sato, T.R. Sleep-Stage-Specific Regulation of Cortical Excitation and Inhibition. Curr. Biol. 2016, 26, 2739-2749. [CrossRef] [PubMed]

237. Harkness, J.H.; Gonzalez, A.E.; Bushana, P.N.; Jorgensen, E.T.; Hegarty, D.M.; Di Nardo, A.A.; Prochiantz, A.; Wisor, J.P.; Aicher, S.A.; Brown, T.E.; et al. Diurnal changes in perineuronal nets and parvalbumin neurons in the rat medial prefrontal cortex. Brain Struct. Funct. 2021, 226, 1135-1153. [CrossRef]

238. Murray, A.J.; Woloszynowska-Fraser, M.U.; Bollepalli, L.; Cole, K.L.H.; Foggetti, A.; Crouch, B.; Riedel, G.; Wulff, P. Parvalbuminpositive interneurons of the prefrontal cortex support working memory and cognitive flexibility. Sci. Rep. 2015, 5, 16778. [CrossRef]

239. Scheggia, D.; Managò, F.; Maltese, F.; Bruni, S.; Nigro, M.; Dautan, D.; Latuske, P.; Contarini, G.; Gomez-Gonzalo, M.; Requie, L.M.; et al. Somatostatin interneurons in the prefrontal cortex control affective state discrimination in mice. Nat. Neurosci. 2019, 23, 47-60. [CrossRef] 
240. Kamigaki, T.; Dan, Y. Delay activity of specific prefrontal interneuron subtypes modulates memory-guided behavior. Nat. Neurosci. 2017, 20, 854-863. [CrossRef]

241. Kato, H.K.; Gillet, S.N.; Isaacson, J.S. Flexible Sensory Representations in Auditory Cortex Driven by Behavioral Relevance. Neuron 2015, 88, 1027-1039. [CrossRef]

242. Natan, R.G.; Briguglio, J.J.; Mwilambwe-Tshilobo, L.; Jones, S.I.; Aizenberg, M.; Goldberg, E.M.; Geffen, M.N. Complementary control of sensory adaptation by two types of cortical interneurons. ELife 2015, 4, e09868. [CrossRef]

243. Natan, R.; Rao, W.; Geffen, M.N. Cortical Interneurons Differentially Shape Frequency Tuning following Adaptation. Cell Rep. 2017, 21, 878-890. [CrossRef]

244. Zhang, S.; Xu, M.; Kamigaki, T.; Do, J.P.H.; Chang, W.-C.; Jenvay, S.; Miyamichi, K.; Luo, L.; Dan, Y. Long-range and local circuits for top-down modulation of visual cortex processing. Science 2014, 345, 660-665. [CrossRef]

245. Kim, D.; Jeong, H.; Lee, J.; Ghim, J.-W.; Her, E.S.; Lee, S.-H.; Jung, M.W. Distinct Roles of Parvalbumin- and SomatostatinExpressing Interneurons in Working Memory. Neuron 2016, 92, 902-915. [CrossRef] [PubMed]

246. Xu, H.; Liu, L.; Tian, Y.; Wang, J.; Li, J.; Zheng, J.; Zhao, H.; He, M.; Xu, T.-L.; Duan, S.; et al. A Disinhibitory Microcircuit Mediates Conditioned Social Fear in the Prefrontal Cortex. Neuron 2019, 102, 668-682.e5. [CrossRef]

247. Wang, J.; Tian, Y.; Zeng, L.-H.; Xu, H. Prefrontal Disinhibition in Social Fear: A Vital Action of Somatostatin Interneurons. Front. Cell. Neurosci. 2020, 14, 611732. [CrossRef]

248. Veit, J.; Hakim, R.; Jadi, M.P.; Sejnowski, T.J.; Adesnik, H. Cortical gamma band synchronization through somatostatin interneurons. Nat. Neurosci. 2017, 20, 951-959. [CrossRef]

249. Toth, K.; Borhegyi, Z.; Freund, T. Postsynaptic targets of GABAergic hippocampal neurons in the medial septum-diagonal band of broca complex. J. Neurosci. 1993, 13, 3712-3724. [CrossRef]

250. Gulyás, A.I.; Hajos, N.; Katona, I.; Freund, T.F. Interneurons are the local targets of hippocampal inhibitory cells which project to the medial septum. Eur. J. Neurosci. 2003, 17, 1861-1872. [CrossRef]

251. Jinno, S.; Klausberger, T.; Marton, L.F.; Dalezios, Y.; Roberts, J.D.B.; Fuentealba, P.; Bushong, E.A.; Henze, D.; Buzsáki, G.; Somogyi, P. Neuronal Diversity in GABAergic Long-Range Projections from the Hippocampus. J. Neurosci. 2007, 27, 8790-8804. [CrossRef]

252. Espinosa, N.; Alonso, A.; Lara-Vasquez, A.; Fuentealba, P. Basal forebrain somatostatin cells differentially regulate local gamma oscillations and functionally segregate motor and cognitive circuits. Sci. Rep. 2019, 9, 2570. [CrossRef]

253. Levitis, D.A.; Lidicker, W.Z.; Freund, G. Behavioural biologists do not agree on what constitutes behaviour. Anim. Behav. 2009, 78, 103-110. [CrossRef]

254. Lewis, D.A.; Hashimoto, T.; Volk, D.W. Cortical inhibitory neurons and schizophrenia. Nat. Rev. Neurosci. 2005, 6, 312-324. [CrossRef]

255. Volk, D.W.; Edelson, J.R.; Lewis, D. Cortical Inhibitory Neuron Disturbances in Schizophrenia: Role of the Ontogenetic Transcription Factor Lhx6. Schizophr. Bull. 2014, 40, 1053-1061. [CrossRef]

256. Volk, D.W.; Lewis, D.A. Early Developmental Disturbances of Cortical Inhibitory Neurons: Contribution to Cognitive Deficits in Schizophrenia. Schizophr. Bull. 2014, 40, 952-957. [CrossRef]

257. Powell, E.M.; Campbell, D.; Stanwood, G.D.; Davis, C.; Noebels, J.; Levitt, P. Genetic Disruption of Cortical Interneuron Development Causes Region- and GABA Cell Type-Specific Deficits, Epilepsy, and Behavioral Dysfunction. J. Neurosci. 2003, 23, 622-631. [CrossRef]

258. Steullet, P.; Cabungcal, J.-H.; Coyle, J.; Didriksen, M.; Gill, K.; Grace, A.A.; Hensch, T.K.; LaMantia, A.-S.; Lindemann, L.; Maynard, T.; et al. Oxidative stress-driven parvalbumin interneuron impairment as a common mechanism in models of schizophrenia. Mol. Psychiatry 2017, 22, 936-943. [CrossRef]

259. Paterno, R.; Casalia, M.; Baraban, S.C. Interneuron deficits in neurodevelopmental disorders: Implications for disease pathology and interneuron-based therapies. Eur. J. Paediatr. Neurol. 2019, 24, 81-88. [CrossRef]

260. Ruden, J.B.; Dugan, L.L.; Konradi, C. Parvalbumin interneuron vulnerability and brain disorders. Neuropsychopharmacology 2020, 46, 279-287. [CrossRef] [PubMed]

261. Vogt, D.; Cho, K.; Lee, A.T.; Sohal, V.S.; Rubenstein, J.L. The Parvalbumin/Somatostatin Ratio Is Increased in Pten Mutant Mice and by Human PTEN ASD Alleles. Cell Rep. 2015, 11, 944-956. [CrossRef] [PubMed]

262. Zhang, L.; Qin, Z.; Ricke, K.M.; Cruz, S.A.; Stewart, A.F.R.; Chen, H.-H. Hyperactivated PTP1B phosphatase in parvalbumin neurons alters anterior cingulate inhibitory circuits and induces autism-like behaviors. Nat. Commun. 2020, 11, 1-15. [CrossRef] [PubMed]

263. Haji, N.; Riebe, I.; Aguilar-Valles, A.; Artinian, J.; Laplante, I.; Lacaille, J.-C. Tsc1 haploinsufficiency in Nkx2.1 cells upregulates hippocampal interneuron mTORC1 activity, impairs pyramidal cell synaptic inhibition, and alters contextual fear discrimination and spatial working memory in mice. Mol. Autism 2020, 11, 29. [CrossRef] [PubMed]

264. Liu, X.; Novosedlik, N.; Wang, A.; Hudson, M.L.; Cohen, I.L.; Chudley, A.E.; Forster-Gibson, C.J.; Lewis, S.M.E.; Holden, J.J.A The DLX1and DLX2 genes and susceptibility to autism spectrum disorders. Eur. J. Hum. Genet. 2008, 17, 228-235. [CrossRef]

265. Batista-Brito, R.; Rossignol, E.; Leffler, J.H.; Denaxa, M.; Wegner, M.; Lefebvre, V.; Pachnis, V.; Fishell, G. The Cell-Intrinsic Requirement of Sox6 for Cortical Interneuron Development. Neuron 2009, 63, 466-481. [CrossRef]

266. Powell, E.M. Interneuron Development and Epilepsy: Early Genetic Defects Cause Long-Term Consequences in Seizures and Susceptibility. Epilepsy Curr. 2013, 13, 172-176. [CrossRef] 